\title{
Low-Temperature Pyrolysis of Coal to Produce Diesel-Fuel Blends
}

Toby B. Shafer

Orlando J. Jett

Jiann-Shing Wu

DO NOT MICROFILM

COVER

\section{OPERATED BY}

UNION CARBIDE CORPORATION FOR THE UNITED STATES DEPARTMENT OF ENERGY 


\section{DISCLAIMER}

This report was prepared as an account of work sponsored by an agency of the United States Government. Neither the United States Government nor any agency Thereof, nor any of their employees, makes any warranty, express or implied, or assumes any legal liability or responsibility for the accuracy, completeness, or usefulness of any information, apparatus, product, or process disclosed, or represents that its use would not infringe privately owned rights. Reference herein to any specific commercial product, process, or service by trade name, trademark, manufacturer, or otherwise does not necessarily constitute or imply its endorsement, recommendation, or favoring by the United States Government or any agency thereof. The views and opinions of authors expressed herein do not necessarily state or reflect those of the United States Government or any agency thereof. 


\section{DISCLAIMER}

Portions of this document may be illegible in electronic image products. Images are produced from the best available original document. 


\section{Printed in the United States of America. Available from National Technical Information Service \\ U.S. Department of Commerce \\ 5285 Port Royal Road, Springfield, Virginia 22161 \\ NTIS price codes-Printed Copy: A04; Microfiche A01}

This report was prepared as an account of work sponsored by an agency of the United States Government. Neither the United States Government nor any agency thereof, nor any of their employees, makes any warranty, express or implied, or assumes any legal liability or responsibility for the accuracy, completeness, or usefulness of any information, apparatus, product, or process disclosed, or represents that its use would not infringe privately nwner rights Reference herein to any specific commercial product, process, or service by trade name, trademark, manufacturer, or otherwise, does not necessarily constitute or imply its endorsement, recommendation, or favoring by the United States Government or any agency thereof. The views and opinions of authors expressed herein do not necessarily state or reflect those of the I Inited States Government or any agency thereof. 
This report was prepared as an account of work sponsored by an agency of tha United States Government. Neither the United States Government nor any agency thereof, nor any of their employees, makes any warranty. express or implied, or essumas any legal liability of responsibility for the accuracy. completeness. or usefulness ot any information, apparatus, product, or process disclosed, or

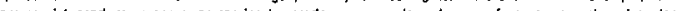

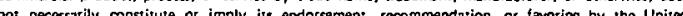
Seves Gover cont ar any or in

Contract No. W-7405-eng-26

ORNL/MIT -355

DE83 001637

ENGINEERING TECHNOLOGY DIVISION

LOW-TEMPERATURE PYROLYSIS OF COAL TO

PRODUCE DIESEL-FUEL BLENDS

Toby B. Shafer

Orlando $\mathrm{J}$. Jett

Jiann-Shing Wu

\author{
Consultants: R.L. Graves \\ J.H. Stewart, Jr.
}

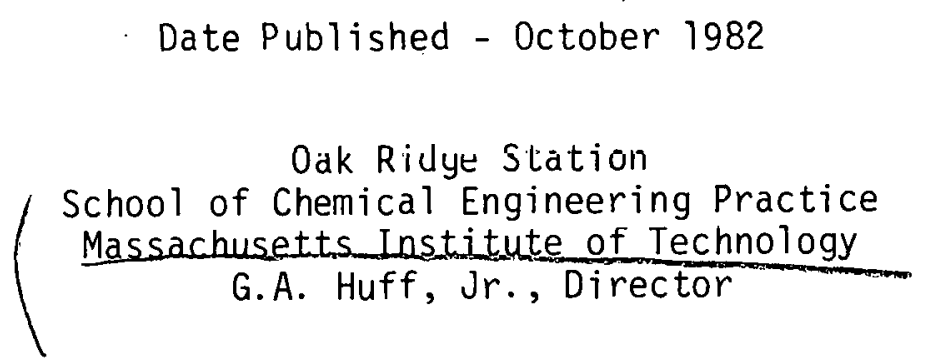

\footnotetext{
Oak Ridge National Laburátory

Oak Ridge, Tennessee 37830 operated by Union Carbide Corporation for the Department of Energy
} 


\section{THIS PAGE \\ WAS INTENTIONALLY LEFT BLANK}


Low-temperature $(623$ to $773 \mathrm{~K}$ ) coal pyrolysis was investigated in a bench-scale retort. Factorially designed experiments were conducted to determine the effects of temperature, coal-particle size, and nitrogen flow rate on the yield of liquid products. Yield of condensable organic products relative to the proximate coal volatile matter increased by 3.1 and 6.4 wt \% after increasing nitrogen purge flow rate from 0.465 to $1.68 \mathrm{~L} / \mathrm{min}$ and retort temperature from 623 to $723 \mathrm{~K}$, respectively. The liquid product may be suitable for blending with diesel fuel. The viscosity and density of coal liquids produced at $723 \mathrm{~K}$ were compared with those of diesel fuel. The coal liquids had a higher carbon-to-hydrogen ratio and a lower aliphatic-to-aromatic ratio than premium quality No. 2 diesel fuel. It was recommended that liquids from coal pyrolysis be blended with diesel fuel to determine stability of the mixture and performance of the blend in internal combustion engines. 



\section{Contents}

Page

1. Summary $\ldots \ldots \ldots \ldots \ldots \ldots \ldots \ldots \ldots \ldots \ldots \ldots \ldots \ldots \ldots \ldots \ldots \ldots \ldots \ldots$

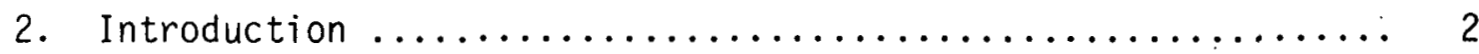

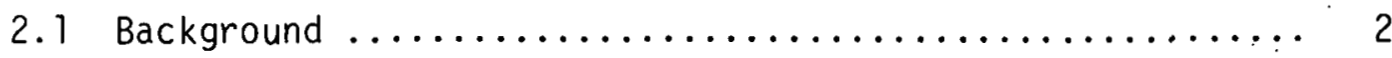

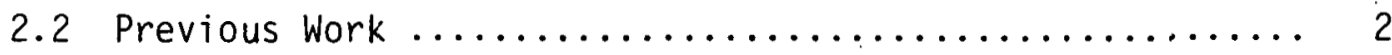

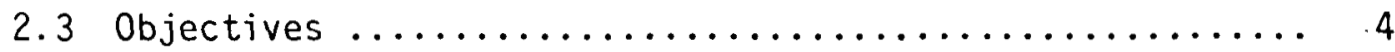

3. Apparatus and Procedure $\ldots \ldots \ldots \ldots \ldots \ldots \ldots \ldots \ldots \ldots \ldots \ldots \ldots$

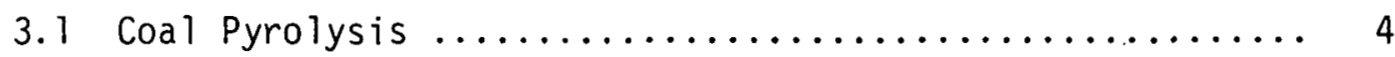

3.2 Coal Product Analysis .......................... 6

3.3 Experimental Design and Procedure................ 7

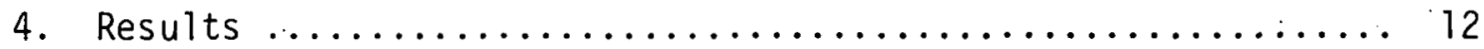

5. Discussion of Results ....................... 20

5.1 Factorial Design ......................... 20

5.2 Compatibility of Coal Liquids with Diesel Fuel ....... 20

5.3 Coal.Pyrolysis Material Balance ................. 21

5.4 Properties of Coal-Pyrolysis Liquids Produced from Dean Seam \#3 Coal .............................. 21

5.5 Physical-Property Correlations ............... 21

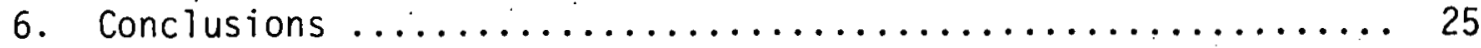

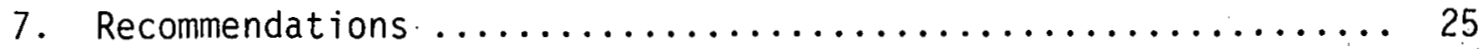

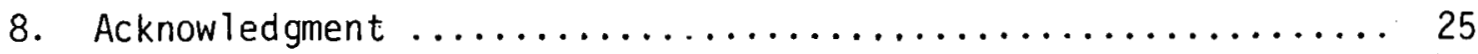

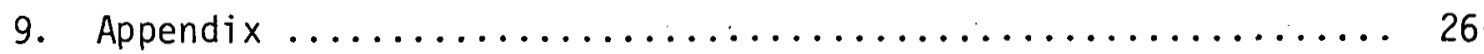

9.1 Methods of Determining Aliphatic-to-Aromatic Ratio ..... 26

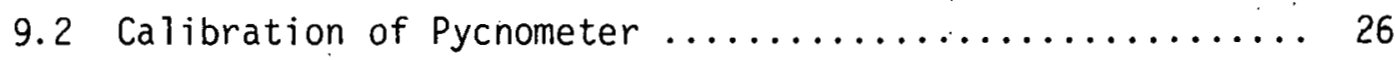

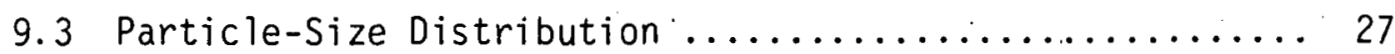

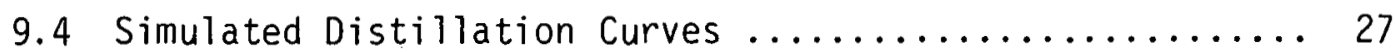

9.5 Weight of Coal Liquids and Water Produced ........... 42

9.6 Yates' Algorithm ........................ 42

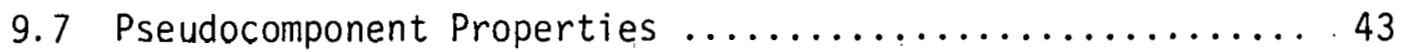

9.8 Location of Original Data .................. 43

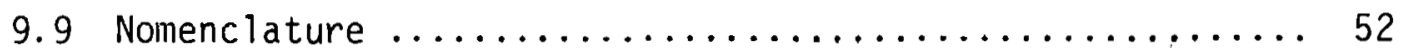

9.10 Literature References ..................... 52 


\section{SUMMARY}

Hydrocarbon liquids produced by low-temperature (623 to $773 \mathrm{~K}$ ) pyrolysis of coal contain less nitrogen and carcinogenic polyaromatic compounds and have a higher aliphatic content than pyrolysis liquids produced at temperatures greater than $773 \mathrm{~K}(\underline{5})$. These qualities are expected to make low-temperature pyrolysis liquids compatible for blending with petroleumbased diesel fuels.

The Engineering Technology.Division of ORNL is studying the pyrolysis of coal at low temperatures to characterize the liquids produced and to test blends of these liquids with diesel fuel in an internal combustion engine. About $650 \mathrm{~g}$ of coal was charged to a bench-scale retort and pyrolyzed in a nitrogen atmosphere. Volatile products were condensed with a chilled-water heat exchanger and collected in a flask. The dependence of volatile yield, hydrocarbon liquid composition (hydrogen-to-carbon and aliphatic-to-aromatic ratios), and the boiling-point range of the liquid product on retort temperature, coal particle size, and flow rate of nitrogen purge gas was investigated with experiments designed by a twolevel factorial approach. Experimental conditions were: retort temperatures of 623 and $723 \mathrm{~K}$, coal-particle sizes ranging up to $0.2 \mathrm{~cm}(-10$ +1 mesh) and 0.06 to $0.48 \mathrm{~cm}(-4+30$ mesh $)$, and purge-gas flow rates of 0.465 and $1.68 \mathrm{~L} / \mathrm{min}$.

The yield of volatile matter was found to depend on retort temperature and the flow rate of the nitrogen purge gas. Volatile yield increased five-fold after increasing the retort temperature from 623 to $723 \mathrm{~K}$. The volatile yield doubled after changing the purge-gas flow rate from 0.465 to $1.68 \mathrm{~L} / \mathrm{min}$.

The composition of the pyrolysis liquids was compared with a sample of diesel fuel. The viscosity and density of the coal liquids produced at $723 \mathrm{~K}$ were similar to those of diesel fuel. The aliphatic-to-aromatic ratio of the pyrolysis liquids ranged from 2.33 to 3.27 , while that of diesel fuel was 5.28. The carbon-to-hydrogen ratio of the pyrolysis liquids was higher than the diesel fuel. However, analysis of the diesel fuel revealed that it contained fewer aromatics than average No. 2 diesel oil.

The miscibility of coal-pyrolysis liquid and diesel fuel should be determined by observing whether precipitates or emulsions are formed when the two liquids are blended. The coal-pyrolysis liquids for these blending tests should be produced under retort conditions of $723 \mathrm{~K}$ and purgegas flow rates between 0.465 to $1.68 \mathrm{~L} / \mathrm{min}$. The maximum retort temperature at which high-quality pyrolysis liquids are produced should be further investigated. Although higher yields were obtained at $723 \mathrm{~K}$, oil quality was similar to that produced at $623 \mathrm{~K}$. 


\section{INTRODUCTION}

\subsection{Background}

Most coal conversion processes upgrade the hydrogen content of the organic fuel produced. Coal pyrolysis produces a volatile fraction rich in hydrogenated species and a carbon-rich residual char. When coal pyrolys is is conducted at low temperatures, 623 to $773 \mathrm{~K}$, several advantages are realized over higher-temperature processes:

1. Low-t.emperature pyrolysis is endothermic (11); the total lieding value content of the products is greater than that of the untreated coal.

2.: At low temperatures, bound nitrogen is seldom evolved as an oxygenated species.

3. Although liquid hydrocarbons are evolved at a slower rate, the aliphatic content is high for pyrolysis temperatures below $773 \mathrm{~K}$. This is indicated graphically in Fig. 1 for a Roland-seam sub-bituminous coal (50-g sample) pyrolyzed at a constant heating rate $(3.33 \mathrm{~K} / \mathrm{min})$ in an argon-swept, packed-bed retort $(\underline{5})$.

These qualities are expected to make the low-temperature pyrolysis liquids compatible with petroleum-based diesel fuels (4). Based on these observations, the Engineering Technology Division of ORNL began an investigation to characterize the pyrolysis liquids from a low-temperature coal retort and to test these liquids blended with diesel fuel in an internal combustion engine.

\subsection{Previous Work}

Several investigators of low-temperature coal pyrolysis used the Fischer-retort method $(6,15,17)$. In a Fischer retort, 20 to $100 \mathrm{~g}$ of coal is slowly heated in an aluminum tube to a temperature between 673 to $873 \mathrm{~K}$. The effluent vapors are condensed and collected.

Sass (17) examined the pyrolysis of Kentucky \#9, high-volatile grade $B$, bituminous coal in a Fischer retort at $773 \mathrm{~K}$.. In comparing the Fischer assay with results of entrained-flow pyrolysis at 803 to $923 \mathrm{~K}$, Sass reported much lower volatile yields. (approximately 26 wt \% of the coal) from the retort procedure. However, there is not a common basis for comparison because of the difference between the temperatures.

A study by Peters and Bertling (15) compared the Fischer-retort method with a stirred-bed pyrolysis unit charged with a Furst-Leopold type of coal. Both pyrolysis units were operated at $873 \mathrm{~K}$. Yields of liquid were higher from the stirred-bed unit, whereas the Fischer assay yielded larger 


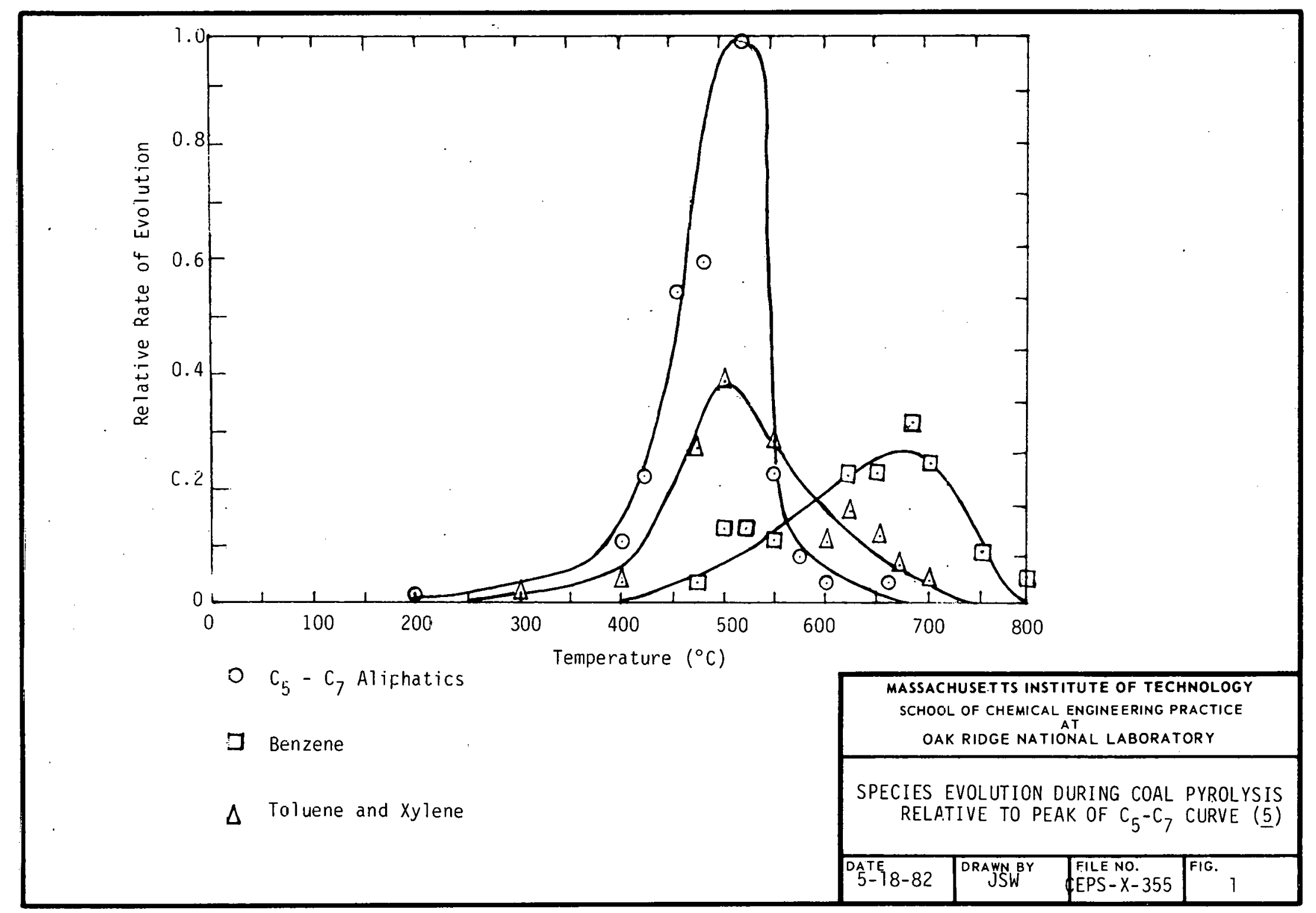


amounts of coke, noncondensible volatiles, and pyrolysis water. The morerapid pyrolysis conditions of the stirred-bed unit reduced the extent of secondary cracking reactions that convert tar (heavy coal liquids) to gas and char (11). Secondary cracking reactions and carbon deposition in the Fischer retort enhanced formation of 1 ight $0 i 1$ and char.

\subsection{Objective}

The objective of this project was to obtain and characterize lowtemperature coal-pyrolysis liquids evolved from Kentucky \#9 coal. The specific goals were to:

1. Determine the effect of temperature, particle size, and inert-gas flow rate on the yield, hydrogen-to-carbon ratio, boiling points (from simulated distillation curves), and the aliphatic-to-aromatic ratio of codjl-pyrulysis 11quits. standard.

2. Compare the qualities of coal-pyrolysis liquids with a diesel-fuel

3. Predict critical properties, molecular weight, and specific gravity of coal liquids and diesel fuel with the Wilson correlations.

\section{APPARATUS AND PROCEDURE}

\subsection{Coal Pyrolysis}

The coal pyrolysis apparatus is shown in Fig. 2. The reactor consisted of a 9.08-cm (2-in.) ID by $40.6-\mathrm{cm}$ (16-in.) long carbon-steel tube placed in an insulated electric furnace, with a variac to control heating. Volatile materials were swept out of the reactor by a nitrngen purge stream. A needle valve controlled the gas flow rate and a Bourdon-tube gauge measured the system pressure, which was close to atmospheric.

The inlet gas stream was preheated by passing it through a tube wrapped around: the outside wall of the vessel and in the irside.wall of the insulated furnace. The effluent gas from the outlet of the reactor was condensed by heat exchange with ice water. The condensed products were collected, and the noncondensable vapor was vented into an exhaust hood at less than $311 \mathrm{~K}$ $\left(100^{\circ} \mathrm{F}\right)$, the lowest recoverable temperature.

Six thermocouples were used to measure the temperature at various points in the apparatus. Two thermocouples measured the reactor-outer-wall temperature, one located $12.7 \mathrm{~cm}$ (5 in.) from the bottom of the reactor and the other $7.62 \mathrm{~cm}$ ( $3 \mathrm{in.}$ ) from the top of the reactor. The temperature of the center of the vessel was measured with two thermocouples located 


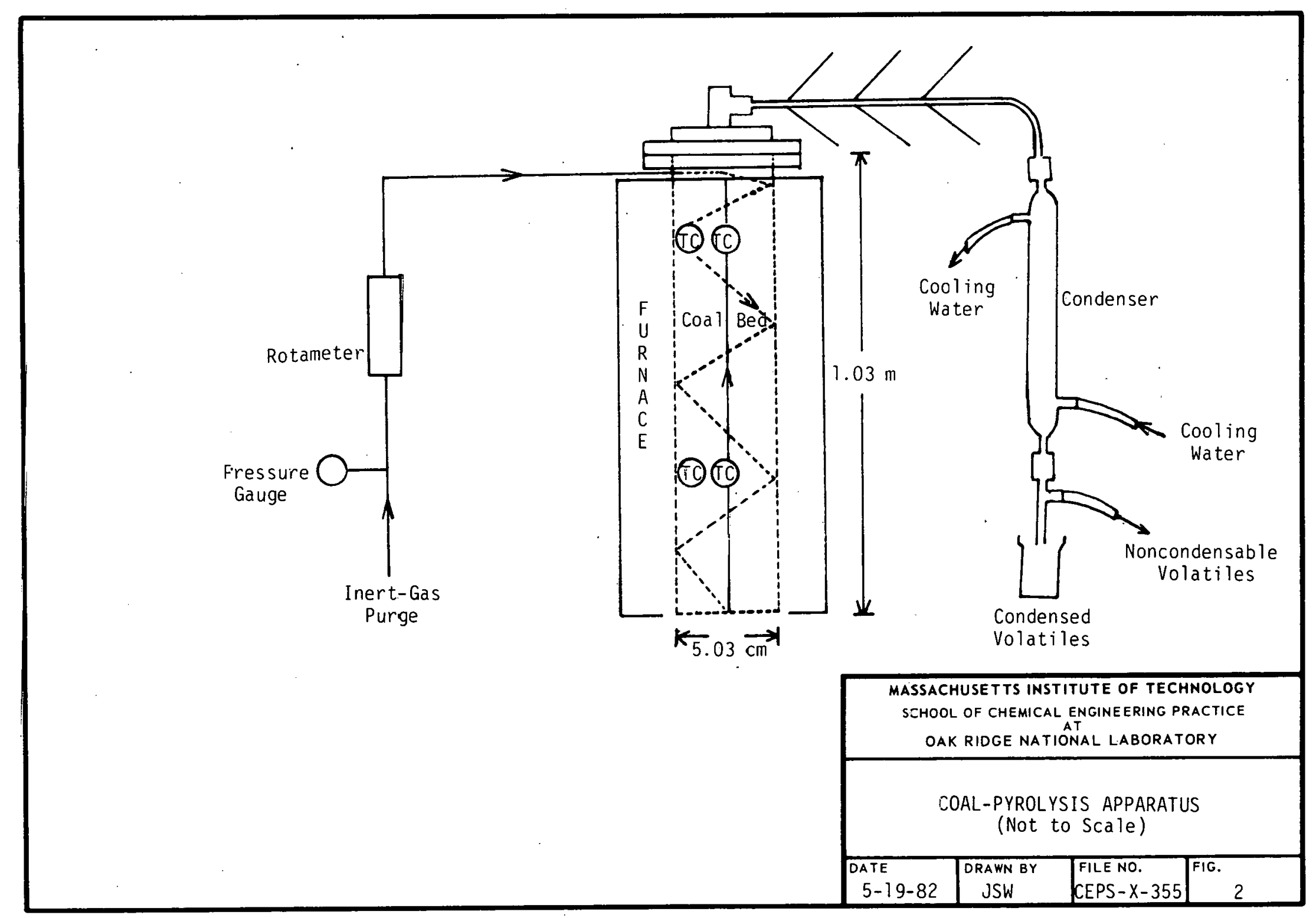

U 
across the reactor vessel, as illustrated in Fig. 2. The other two thermocouples measured the temperature of the effluent gas at the outlet of the vessel and the condenser.

About $640 \mathrm{~g}$ of Kentucky \#9 bituminous or Dean Seam \#3 coal was charged to the reactor, which had been opened by a flange at the top before each run. The outlet tube and the space between the furnace wall and outside reactor wallwere insulated with glass wool to minimize axial temperature gradients through the reactor and to avoid condensing volatile material inside the tube that connected the condenser and vessel.

After the reactor top was sealed, purge gas was passed through the vessel and furnace heating begun. The rate of temperature increase was about $500^{\circ} \mathrm{K} / \mathrm{h}$ until the reactor approached the desired temperature, after which the heating rate was decreased until all four reactor thermocouples indicated that temperatures were within $11 \mathrm{~K}\left(20^{\circ} \mathrm{F}\right)$ of the desired temperature. The final temperature was maintained for 3 to $4 \mathrm{~h}$.

The condensed coal liquids were collected in three fractions. The first contained liquids collected while the reactor temperature was increasing; the second consisted of coal liquids produced while the reactor was at the final temperature; and the third fraction included the remaining coal liquids collected while the reactor conled overnight (about $15 \mathrm{~h}$ ) to room temperature. For selected runs, the flow rate of noncondensable gas from the pyrolysis unit was measured with a soap-film bubble flowmeter.

The char was removed from the cooled reactor and weighed. The condenser and connecting tubes were flushed with acetonne to remove any residue and thus avoid contamination of products from different experiments. Water was removed from the organic liquid with a separatory funnel before l.he rọal liguids were analyzed.

\subsection{Coal-Product Analysis}

The yield, aliphatic-to-aromatic ratio, boiling-point dislribution, and carbon-to-hydrogen ratio of all coal-pyrolysis liquids collerted, and lhe density, viscosity, sulfur, and nitrogen content of selected liquid samples were measured. The composition of the gas leaving the condenser was determined for one run, and the volatile, moisture, and ash contents of the Kentucky \#9 coni and three difforent samples of char were measured to complete a material balance around the reactor.

Yield is defined as the collected weight of coal--pyrolysis liquid relative to the total weight of volatile matter in the coal charged to the reactor as determined by proximate analysis. Nuclear magnetic resonance (NMR) spectroscopy was used by the Analytical Chemistry Division to determine the aliphatic-to-aromatic ratio. With NMR, molecular groups near hydrogen atoms are differentiated by measuring the absorption of 
visible light as the hydrogen energy levels change with magnetic-field frequencies (16). The aliphatic-to-aromatic ratio was calculated by dividing the percentage of hydrogen atoms attached to aliphatic groups by the percentage of hydrogen atoms attached to aromatic groups. The disadvantage of NMR is that molecules that contain both aliphatic and aromatic groups are counted twice. These aliphatic and aromatic compounds could not be satisfactorily separated on a gel chromatographic column, as discussed in Appendix 9.1.

The boiling points of the pyrolysis liquids were determined by a simulated distillation technique performed by the Analytical Chemistry Division, with a Shimadzu GCGA gas chromatograph and a Sigma 10 PerkinElmer integrating chart recorder. To obtain a smoother curve, the components were assumed to be straight-chain hydrocarbons.

The carbon and hydrogen content of the pyrolysis liquid was determined by oxidizing the liquid sample in a Lindberg carbon $\div$ hydrogen analyzer. The hydrogen reacted with oxygen to form water, which was adsorbed and weighed. The carbon reacted with oxygen to form carbon dioxide, which was adsorbed separately and weighed. The percentage of carbon and hydrogen in the sample was calculated by material balance.

If more than $10 \mathrm{~cm}^{3}$ of the coal liquid was collected, the density was measured with a pycnometer, as detailed in Appendix 9.2. The viscosity of the coal-pyrolysis liquid was measured with an Ubbelohde viscometer. The Kjeldhal method was used by Analytical Chemistry (1) to determine the nitrogen content of selected coal liquids, and the sulfur content was determined with a Leco sulfur analyzer.

The gaseous products were separated with a Perkin 3920 gas chromatograph and detected by thermal conductivity at the Analytical Chemistry Division. The volatile, moisture, and ash contents of the coal and char were determined with a Fisher coal analyzer at Analytical Chemistry.

\subsection{Experimental Design and Procedure}

Experiments to determine the effects of reactor conditions on volatile products were designed by two-level factorial statistics. The three

variables (factors) - reactor temperature, coal“particle size, and the volumetric flow rate of purge gas through the reactor - were considered in this design. Each factor was studied at the two levels listed in Table 1 . 
Table 1. Experimental Design Factors and Levels

\begin{tabular}{ccc}
\hline Factor & Low Level & $\frac{\text { High Level }}{$\cline { 3 - 3 } \text {$Reactor temperature }}$ \\
Coal-particle size & $623 \mathrm{~K}$ & $723 \mathrm{~K}$ \\
Purge-gas flow rate & $\begin{array}{c}0 \text { to } 0.2 \mathrm{~cm} \\
(-10+0 \mathrm{mesh})\end{array}$ & $\begin{array}{c}0.059 \text { to } 0.48 \mathrm{~cm} \\
(-4+30 \mathrm{mesh})\end{array}$ \\
\hline
\end{tabular}

The two-level factorial design was appropriate for the exploratory analyses of this pyrolysis study. With the minimum number of runs, the sensitivity to variables was determined, which indicated parameters that should be studied further (3). The factors were examined experimentaliy at each level in all possible combinations. The matrix on which these experiments were designed is shown in Table 2. The levels are coded in the lower portion so that a minus sign represents the low level and a plus sign the high level of each variable. Experiments were conducted at each of the eight retort conditions described in the matrix. The dependence of volatile yield, final boiling point, aliphatic-to-aromatic ratio, and the carbon-to-hydrogen ratio on retort conditions was determined analytically. The effect of the factors on the various responses was calculated by an algorithm developed by Yates and described in Appendix 9.6. The effect of a factor is defined as the r.hange in the response of that factor when the experimental condition moves from the minus (low). to the plus (high) level.

The symmetry of the faclurial design is geometrically illustrated in Fig. 3. Each vertex of the cube denotes one of the retort conditions described in the design matrix, and the numbers correspond to the run conditions listed in Table 2. The temperature $T$ increases from the minus $(623 \mathrm{~K})$ to the plus $(723 \mathrm{~K})$ level along the ordinate. The coal-particle size $M$ increases from the minus $(0$ to $0.2 \mathrm{~cm})$ to the plus $(0.059$ to $0.48 \mathrm{~cm})$ level along the abscissa. The purge-gas flow rate $F$ increases from minus $(0.465 \mathrm{~L} / \mathrm{min})$ to plus $(1.68 \mathrm{~L} / \mathrm{min})$ on the axis extending out of the plane of the page.

Experiments were designed by factorial statistics in the following manner. We shall discuss the effect of temperature first. The responses between conditions 1 and 2 in Fig. 3 differ only due to the change in temperature. There are four measures of the change in response caused by temperature. The main effect of temperature is the difference between the average response of the plus levels and the average response of the minus level. In lerils of corresponding retort conditions, this is:

$$
T^{\prime}=\frac{y_{2}+y_{4}+y_{6}+y_{8}}{4}-\frac{y_{1}+y_{3}+y_{5}+y_{7}}{4}
$$


Table 2. Factorial Design Matrix

\begin{tabular}{cccc}
$\begin{array}{c}\text { Experiment } \\
\text { No. }\end{array}$ & $\begin{array}{c}\text { Temperature } \\
(\mathrm{K})\end{array}$ & $\begin{array}{c}\text { Coal Particle Size } \\
(\mathrm{cm})(\mathrm{mesh})\end{array}$ & $\begin{array}{c}\text { Purge-Gas Flow Rate } \\
(\mathrm{L} / \mathrm{min})\end{array}$ \\
\hline
\end{tabular}

a. Original Units of Variables

$\begin{array}{lccc}1 & 623 & 0 \text { to } 0.2(-10+0) & 0.465 \\ 2 & 723 & 0 \text { to } 0.2(-10+0) & 0.465 \\ 3 & 623 & 0.059 \text { to } 0.48(-4+30) & 0.465 \\ 4 & 723 & 0.059 \text { to } 0.48(-4+30) & 0.465 \\ 5 & 623 & 0 \text { to } 0.2(-10+0) & 1.68 \\ 6 & 723 & 0 \text { to } 0.2(-10+0) & 1.68 \\ 7 & 623 & 0.059 \text { to } 0.48(-4+30) & 1.68 \\ 8 & 723 & 0.059 \text { to } 0.48(-4+30) & 1.68\end{array}$

b. Coded Units of Variables

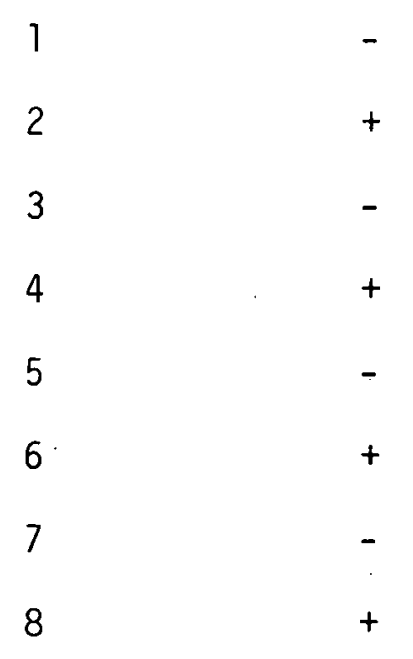

Temperature (K) Coal-Particle Size (cm)(mesh) Purge-Gas Flow Rate (L/min)

\begin{tabular}{cccccc}
- & + & 0 & + & + \\
623 & 723 & $\begin{array}{c}\text { to } 0.2 \\
(-10+0)\end{array}$ & $\begin{array}{c}0.059 \text { to } 0.48 \\
(-4+30)\end{array}$ & 0.465 & 1.68 \\
\hline
\end{tabular}

${ }^{a}$ See Appendix 9.2 for particle-size distribution. 


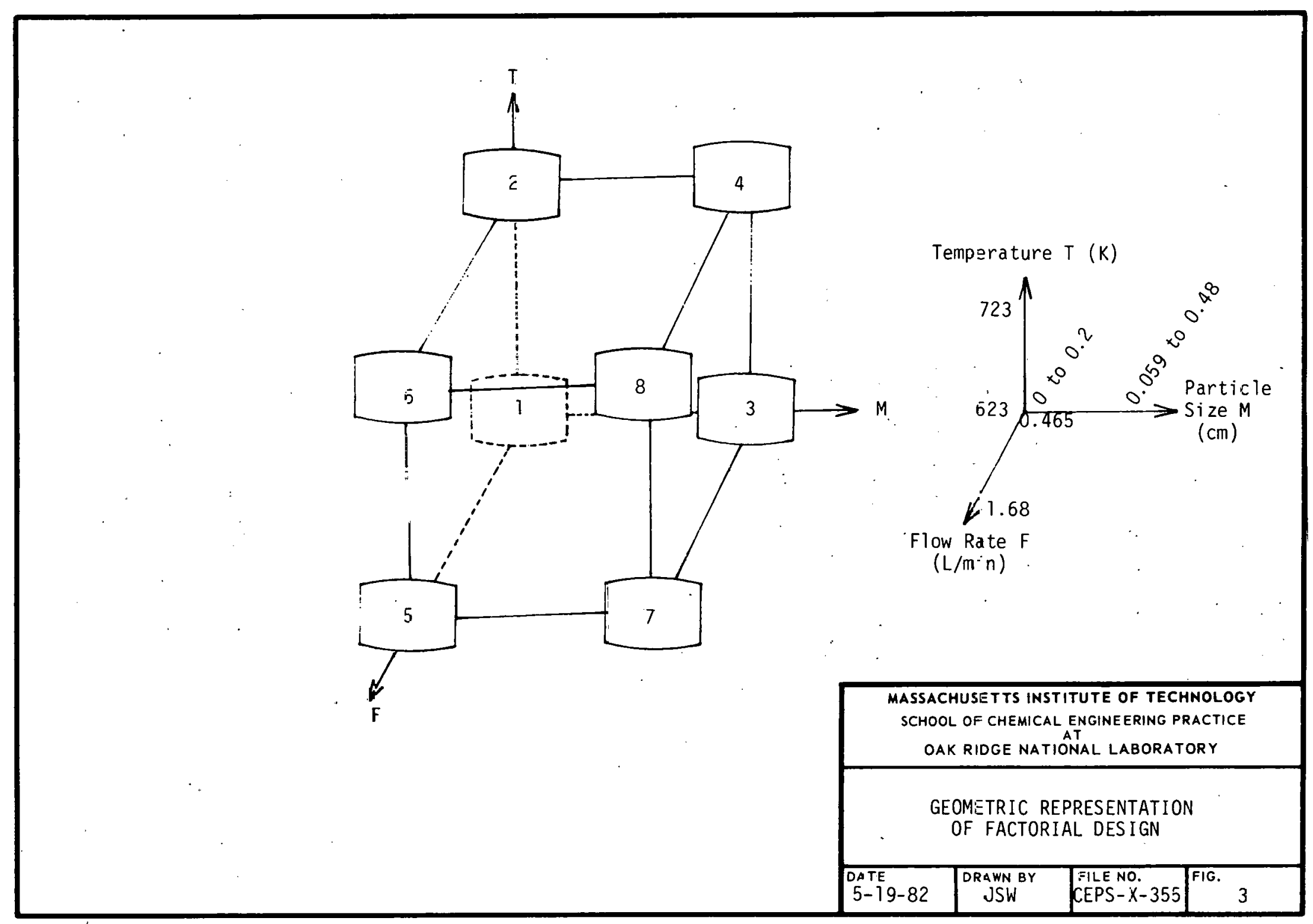


where $y_{j}$ is the response, such as yield, at the $i$ th experimental condition, and $T^{\prime}$ denotes the main effect of temperature. The main effect measures the average effect of temperature over all conditions of coal-particle size and purge-gas flow rate.

The main effects of coal-particle size and purge-gas flow rate are determined similarly. $M$ ' denotes the main effect of particle size and is expressed as:

$$
M^{\prime}=\frac{y_{3}+y_{4}+y_{7}+y_{8}}{4}-\frac{y_{1}+y_{2}+y_{5}+y_{6}}{4}
$$

The main effect of purge-gas flow rate $F^{\prime}$ is:

$$
F^{\prime}=\frac{y_{5}+y_{6}+y_{7}+y_{8}}{4}-\frac{y_{1}+y_{2}+y_{3}+y_{4}}{4}
$$

The effect of a variable, such as temperature, may be markedly different at the low level of a second variable, such as coal-particle size, than at the high level of that variable. In this. case the two variables, temperature and particle size, are said to interact. A measure of this interaction is determined by the difference between the average temperature effect at the high level of particle size and the average temperature effect at the low level of particle size. This temperature-by-particle-size interaction is denoted by the $T^{\prime} X M^{\prime}$ which is expressed as:

$$
T^{\prime} x: M^{\prime}=\frac{y_{1}+y_{4}+y_{5}+y_{8}}{4}-\frac{y_{2}+y_{3}+y_{6}+y_{7}}{4}
$$

Two factor interactions can occur for all three variables. The temperatureby-purge-gas-flow-rate interaction is expressed as:

$$
T^{\prime} \times F^{\prime}=\frac{y_{1}+y_{3}+y_{6}+y_{8}}{4}-\frac{y_{2}+y_{4}+y_{5}+y_{7}}{4}
$$

The particle-size-by-purge-gas-flow-rate interaction is expressed as:

$$
M^{\prime} \times \Gamma^{\prime}-y_{1}+y_{2}+y_{7}+y_{8}-\frac{y_{3}+y_{4}+y_{5}+y_{6}}{4}
$$

Three-factor interactions measure the difference between the average. effect of two-factor interaction T'X.M' at the high level of purge-gas flow rate and the average T'XM' interaction at the low level of purge-gas flow rate. If the three-factor interaction is negligible, then the statistical 
error is a difference of the averages:

$$
T^{\prime} X . M^{\prime} x F^{\prime}=\frac{y_{2}+y_{3}+y_{5}+y_{8}}{4}-\frac{y_{1}+y_{4}+y_{6}+y_{7}}{4}
$$

\section{RESULTS}

The conditions of the eight runs performed to complete the factorial design are listed in Table 2. The effect of temperature, particle size, purge-gas flow rate on yield, maximum boiling pnint, aliphatic-to-aromatic ratio, and carbon-to-hydrogen ratio is shown in Figs. 4 through 7 and in Table 3. Simulated distillation curves are presented in Appendix 9.1, and the weights of water and coal liquids produced and temperature histories are listed in Appendix 9.5.

Both temperature and flow rate affect the pyrolysis liquids. By increasing the temperature from 623 to $723 \mathrm{~K}$, the yield increased by a factor of 5 . By increasing the flow rate from 0.465 to $1.68 \mathrm{~L} / \mathrm{min}$, the yield increased by a factor of 2. Flow rate affects the maximum boiling point, whereas neither the temperature nor particle size affect the aliphatic-to-aromatic and carbon-to-hydrogen ratios.

Table 3. Effect of Run Conditions on Yield, Maximum Boiling Point, and Aliphatic-to-Arnmatir. Ration

\begin{tabular}{|c|c|c|c|}
\hline & $\begin{array}{l}\text { Coal Liquid } \\
\text { Yield }(\%) \\
\end{array}$ & $\begin{array}{l}\text { Maximum Boiling } \\
\text { Point (K) } \\
\end{array}$ & $\begin{array}{c}\text { Aliphatic-to-Aromatic } \\
\text { Ration }\end{array}$ \\
\hline Average & 4.66 & 676 & 5.87 \\
\hline$T^{\prime}$ & +6.40 & +13.5 & -0.56 \\
\hline$M^{\prime}$ & +0.07 & +8.5 & -0.01 \\
\hline$T^{\prime} \times M^{\prime}$ & -1.09 & +11.5 & -0.28 \\
\hline$F^{\prime}$ & +3.09 & +105 & +0.17 \\
\hline$T^{\prime} \times F^{\prime}$ & +2.20 & 0 & +0.30 \\
\hline$M^{\prime} \times F^{\prime}$ & -0.32 & +17 & -0.05 \\
\hline I'XM'X & -0.80 & +36 & -0.43 \\
\hline \multicolumn{4}{|c|}{$\begin{array}{l}T^{\prime}=\text { temperature effect } \\
M^{\prime}=\text { particle-size effect } \\
F^{\prime}=\text { flow--rate effect } \\
+- \text { posilive deviation from average } \\
-=\text { negative deviation from average }\end{array}$} \\
\hline
\end{tabular}




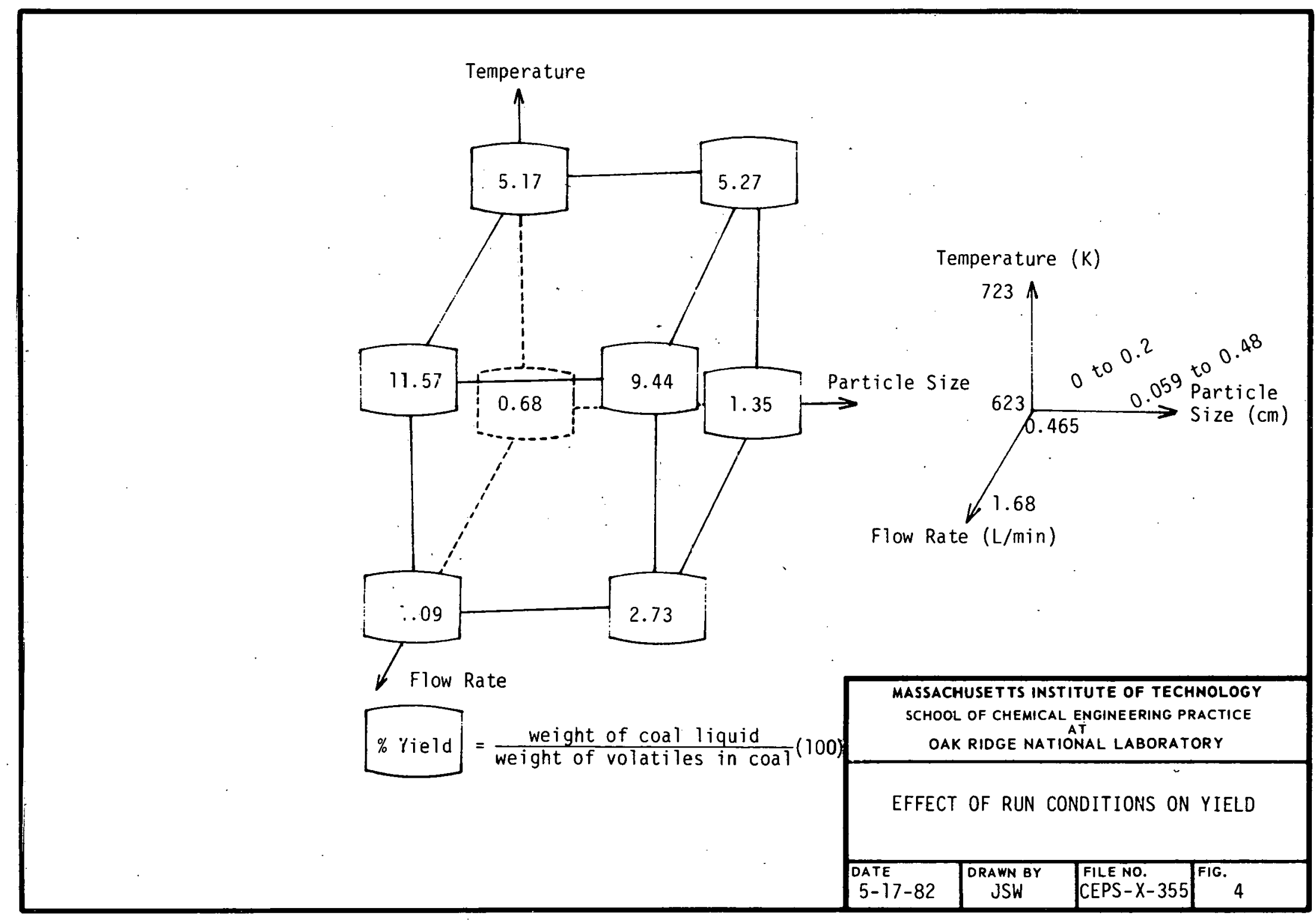




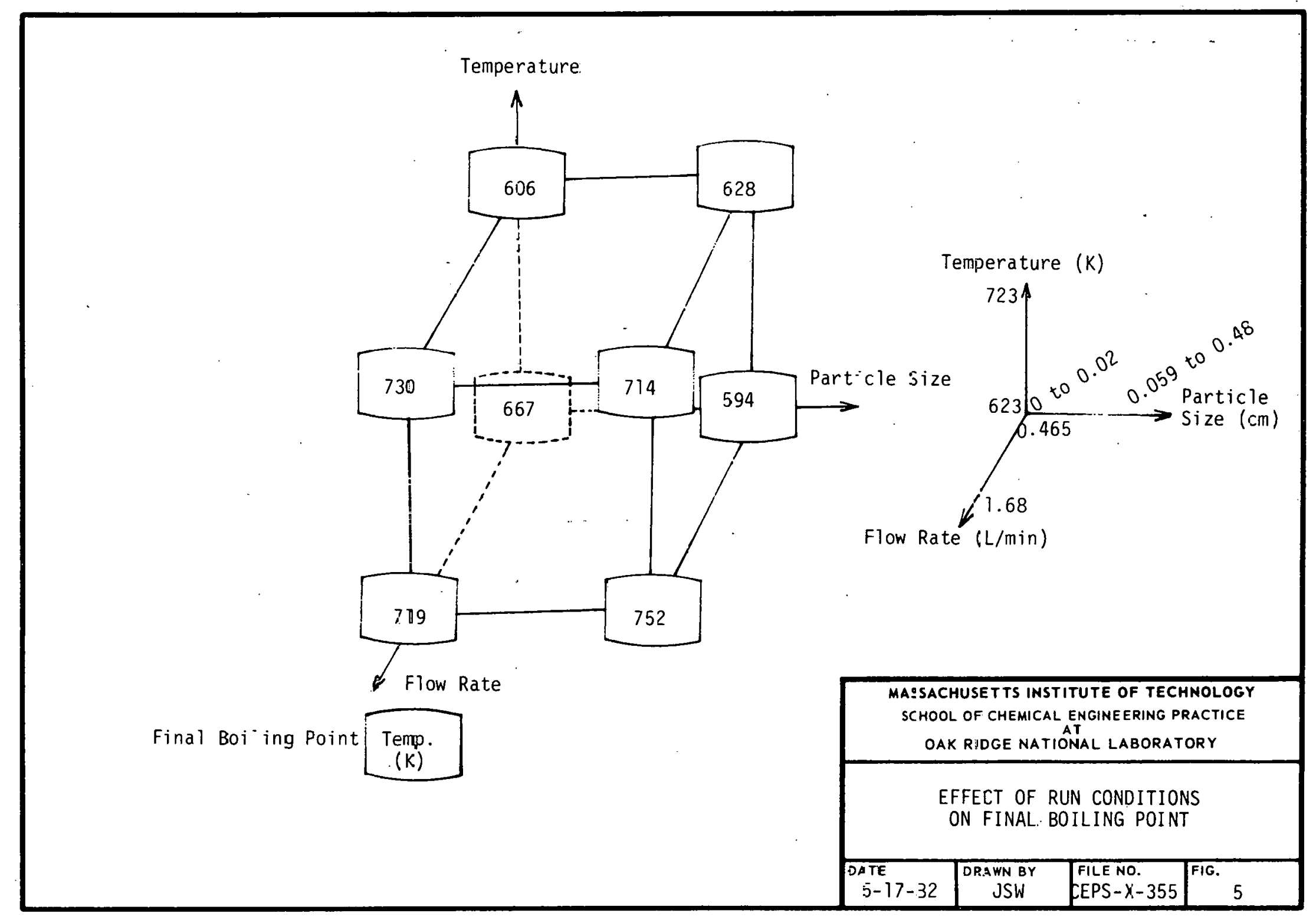




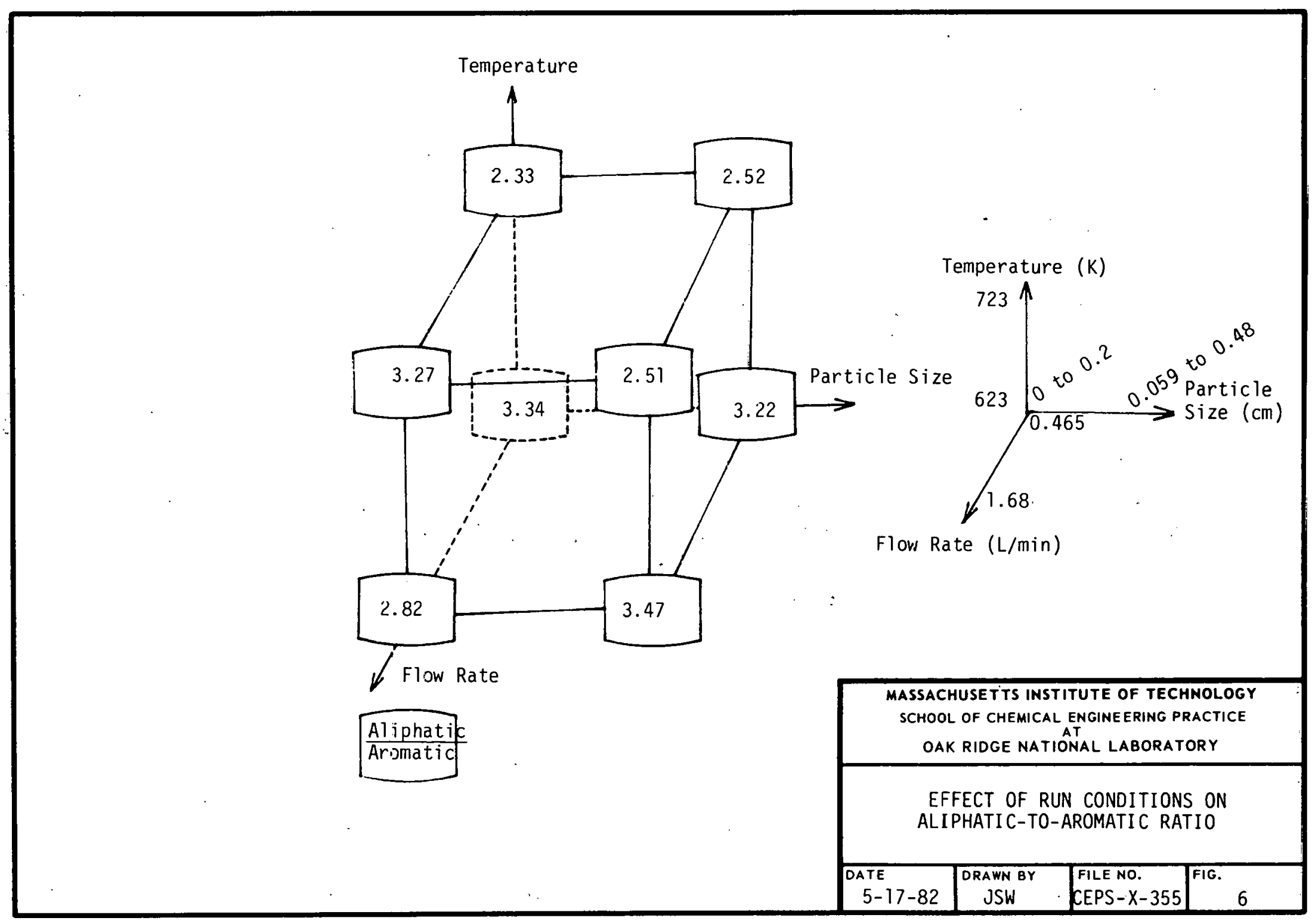




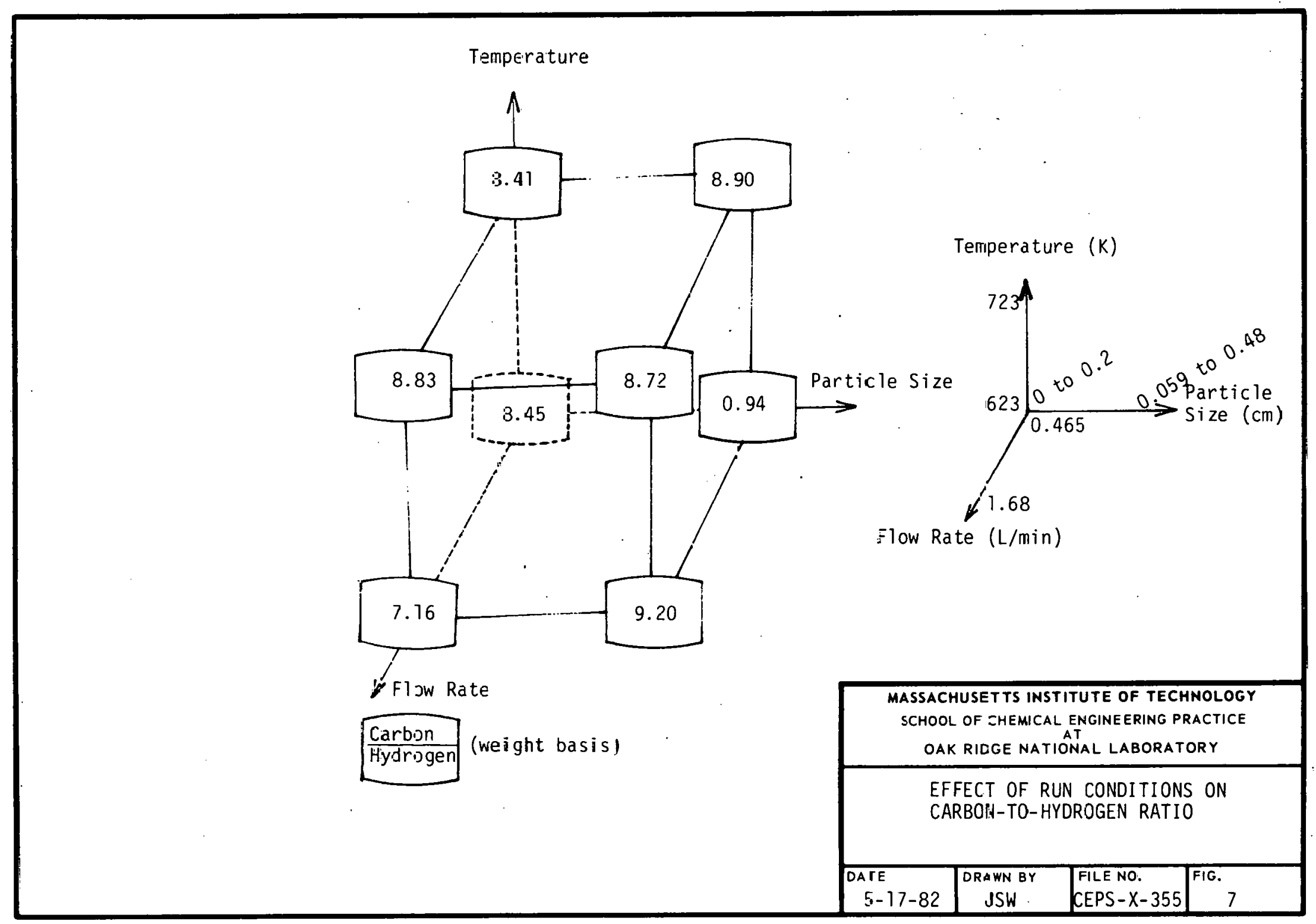


A comparison of the properties of coal-pyrolysis liquids, commercial diesel fuel (CITGO), and diesel fuel reported in the literature (2, 13) is shown in Table 4. The density of coal-pyrolysis liquids is about $12 \%$ higher, the carbon-to-hydrogen ratio is $20 \%$ higher, and the aliphatic-toaromatic ratio of the pyrolysis liquids is almost 50\% lower than those of diesel fuel. The nitrogen content, maximum boiling point, and viscosity of coal-pyrolysis liquids are within the range reported for diesel fuel. The sulfur content is about three times greater than the allowable level for diesel fuel. The difference between the final and initial boiling points is $570 \mathrm{~K}\left(535^{\circ} \mathrm{F}\right)$ for diesel fuel and $625 \mathrm{~K}\left(634^{\circ} \mathrm{F}\right)$ for coalpyrolysis liquids.

Table 4. Comparison of Coal-Pyrolys is Liquids and Diesel Fuel

\begin{tabular}{|c|c|c|c|}
\hline & Coa 1*Pyrolysis & & ese] Fuel \\
\hline & Liquid (723 K) & Commercial & Literature $(\underline{2}, \underline{13})$ \\
\hline Density $(\mathrm{g} / \mathrm{ml})$ & 0.9 to 1.0 & 0.85 & 0.82 to 0.95 \\
\hline Aliphatic/aromatic ratio & 2.33 to 3.27 & 5.28 & - \\
\hline Viscosity, Pa.s (cp) & $\begin{array}{c}3.46 \times 10^{-3} \\
(3.46)^{a}\end{array}$ & $\begin{array}{c}2.98 \times 10^{-3} \\
(2.98)\end{array}$ & $\begin{array}{c}2 \times 10^{-3} \text { to } 4.3 \times 10^{-3} \\
(2 \text { to } 4.3)\end{array}$ \\
\hline Carbon/hydrogen (wt basis) & 8.41 to 8.90 & 6.90 & 5.67 to 8.8 \\
\hline Final boiling point, $K$ & $\begin{array}{l}606 \text { to } 628 \\
\text { or } 714 \text { to } 730^{b}\end{array}$ & 662 & 603 \\
\hline Boiling-point range, $K$ & $\begin{array}{l}557 \text { to } 561 \\
\text { or } 608 \text { to } 657 \mathrm{~b}\end{array}$ & 570 & 393 \\
\hline Sulfur. (wt \%) & $1.35^{\mathrm{a}}$ & 933 ppm & $<0.5 \%$ \\
\hline Nitrogen (wt \%) & 0.04 & 0.04 & - \\
\hline $\begin{array}{l}{ }^{a_{0}} \text { me measurement taken. } \\
b_{F}=0.465 \text { or } 1.68 \mathrm{~L} / \mathrm{min} \text {, }\end{array}$ & ectively. & & \\
\hline $\begin{array}{l}\text { A mass balance for coa } \\
\text { rate, large particle size) } \\
\text { volatiles in the coal chars } \\
\text { effluent product accounts } \\
\text { only } 74 \text { wt } \% \text { of the volati } \\
\text { coal surface, whereas volat } \\
\text { pyrolysis. The composition } \\
\text { the condenser was: } 77 \% \text { air } \\
7.3 \% \text { methane, } 0.72 \% \text { carbon } \\
\text { propane. }\end{array}$ & $\begin{array}{l}\text { 1-pyrolysis run } \\
\text { is presented in } \\
\text { ed are removed. } \\
\text { or } 95 \text { wt \% of co } \\
\text { es. Moisture r } \\
\text { ile water is tha } \\
\text { of the gas stre } \\
\text { and nitrogen, } 15 \\
\text { dioxide, } 0.03 \%\end{array}$ & $\begin{array}{l}\text { (high tempe } \\
\text { able } 5 . \text { Ha } \\
\text { A mass balar } \\
1 \text { charged to } \\
\text { presents ads } \\
\text { chemically } \\
\text { m on a volun } \\
\text { hydrogen, } \\
\text { hylene, } 0.26\end{array}$ & $\begin{array}{l}\text { rature, low flow } \\
\text { f }(49 \text { wt } \%) \text { of the } \\
\text { ce on the char and } \\
\text { the reactor but } \\
\text { orbed water on the } \\
\text { released during } \\
\text { basis leaving } \\
1 \% \text { carbon monoxide, } \\
\% \text { ethane, and } 1 \%\end{array}$ \\
\hline
\end{tabular}


Table 5. Mass Balance for Run 4

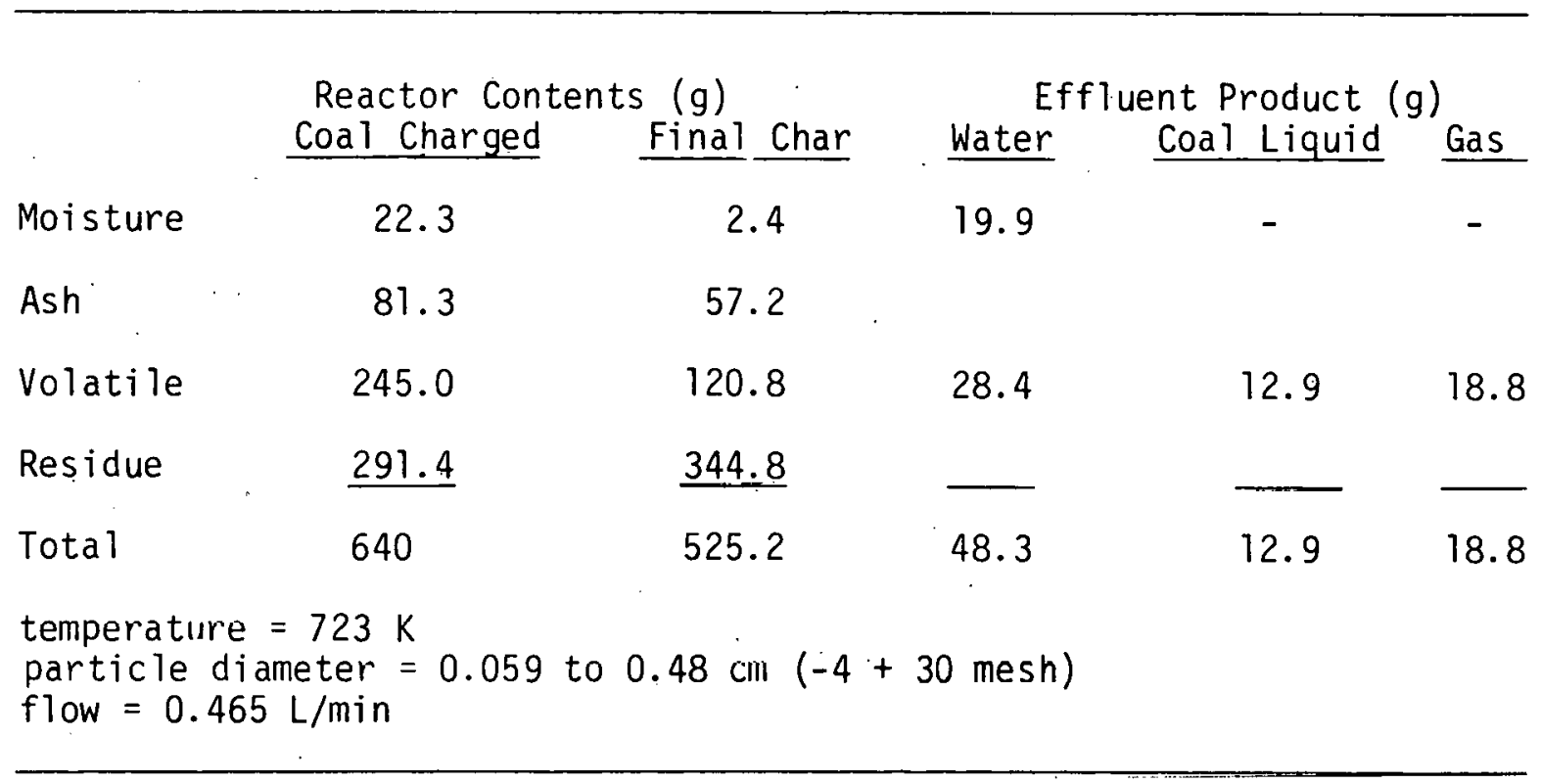

The coal-pyrolysis liquid produced during reactor heat-up was analyzed and compared with the liquid produced after the reactor had reached a final temperature of $723 \mathrm{~K}\left(842^{\circ} \mathrm{F}\right)$. As shown in Table 6 , only the aliphatic-toaromatic ratio differed.

Table 6. Comparison of Coal Liquids Produced Before and After Reactor Reached $723 \mathrm{~K}$

\begin{tabular}{lcc}
\hline & $\leq 723 \mathrm{~K}$ & $.723 \mathrm{~K}$ \\
\cline { 2 - 3 } & 8.6 & 8.7 \\
Carbon-to-hydrogen ratio (wt basis) & 3.60 & 2.51 \\
$\begin{array}{l}\text { Bliphatic-to-aromatic ratio } \\
\text { Boiling-point range }(\mathrm{K})\end{array}$ & 335 to 733 & 379 to 714 \\
$\begin{array}{l}\text { flow rate }=1.68 \mathrm{~L} / \mathrm{min} \\
\text { particle size }=0.059 \text { to } 0.48 \mathrm{~cm}(-4+30 \text { mesh })\end{array}$ \\
\hline
\end{tabular}

The aliphatic-to-aromatic ratio is higher in the pyrolysis liquid produced before the reactor reaches temperature than after; as exemplified by run condition 8 . Since a higher aliphatic-to-aromatic ratio is desirable, the pyrolysis liquids produced before and after the reactor reaches temperature should not be collected separately for industrial operation. No analysis was performed on the mixed liquids. 
The instability of pyrolysis liquids when exposed to ultraviolet light was of concern. A sample of coal liquid produced from run 2 was exposed to sunlight for five days. The analysis of the sample is shown in Table 7. The aliphatic-to-aromatic ratio and maximum boiling point of the liquid increased 5.8 and $40.8 \%$, respectively after exposure because the coal liquid had begun to polymerize (19).

Table 7. Effect of Ultraviolet Light on Coal-Pyrolysis Liquid

\begin{tabular}{lccc}
\hline & $\begin{array}{c}\text { No Exposure } \\
\text { to Sun }\end{array}$ & $\begin{array}{c}\text { Exposure to Sun } \\
\text { for 5 Days }\end{array}$ \\
$\begin{array}{l}\text { Carbon-to-hydrogen ratio (wt basis) } \\
\text { Aliphatic-to-aromatic ratio }\end{array}$ & $\begin{array}{c}2.33 \\
8.41\end{array}$ & 3.28 \\
Builing-point range (K) & 344 to 606 & 338 . to 749 \\
temperature $=723 \mathrm{~K}$ \\
$\begin{array}{l}\text { flow rate }=0.465 \mathrm{~L} / \mathrm{min} \\
\text { particle size }=0 \text { to } 0.2 \mathrm{~cm}(-10+0 \text { mesh) }\end{array}$
\end{tabular}

Coal-pyrolysis liquid was also produced from Dean Seam Coal \#3 mined at Graves' Gap in New River, Anderson County, Tennessee. A comparison beteen this pyrolysis liquid and that produced from Kentucky \#9 coal is shown in Table 8 . The yield was $28 \%$ higher with the Dean Seam coal, and the carbon-to-hydrogen and aliphatic-to-aromatic ratios were 27 and $12 \%$ lower, respectively.

Table 8. Coal Pyrolysis Liquid from Two Coals

\begin{tabular}{|c|c|c|}
\hline & Kentucky \#9 Coal & Dean Seam \#3 Coal \\
\hline Density, $\mathrm{g} / \mathrm{m} \mathrm{l}$ & 1.03 & 0.99 \\
\hline Viscosity, $\mathrm{Pa} \cdot \mathrm{s}(\mathrm{cp})$ & $3.46 \times 10^{-3}(3.46)$ & $3.73 \times 10^{-3}(3.73)$ \\
\hline Carbon-to-hydrogen ratio (wt basis) & 8.9 & 6.5 \\
\hline Aliphatic-to-aromatic ratio & 3.04 & 2.68 \\
\hline Builing-point range $(K)$ & 338 to 744 & 338 to 669 \\
\hline$\%$ Yield $=\left(\frac{\text { wt of coal liquid }}{\text { weight of volatiles }}\right)(100$ & 13.7 & 17.5 \\
\hline \multirow{2}{*}{\multicolumn{3}{|c|}{$\begin{array}{l}\text { temperature }=723 \mathrm{~K} \\
\text { particle size }=0.059 \text { to } 0.48 \mathrm{~cm}(-4+30 \text { mesh })\end{array}$}} \\
\hline & & \\
\hline flow rate $=0.465 \mathrm{~L} / \mathrm{min}$ & & \\
\hline
\end{tabular}




\section{DISCUSSION OF RESULTS}

\subsection{Factorial Design}

From the results of the factorial experiments, the effect of temperature, particle size, and flow rate on the yield, maximum boiling point, aliphatic-to-aromatic hydrocarbon ratio, and carbon-to-hydrogen ratio was determined. The yield (wt of coal liquid/wt of volatiles)(100\%) increases with higher reactor temperature, as observed by Howard (12). Coal should be pyrolyzed at the highest temperature at which the liquid products have the desired properties. Operation at $623 \mathrm{~K}\left(662^{\circ} \mathrm{F}\right)$ is unfeasible because the yield of coal liquids is less than $3 \%$.

Although Smith (18) observed that the aliphatic-to-aromatic ratio decreases with higher temperature, no effect of temperature on the aliphaticto-aromatic ratio was observed in the range studied here. There were several problems with the measurement of the aliphatic-to-aromatic ratio. NMR is not an accurate method for measuring the ratio because molecules can be counted as both aromatic and aliphatic. Another method, such as high-pressure liquid chromatography or liquid extraction with dimethyl siloxane, is needed for accurate measurement of the aliphatic-to-aromatic ratio (20).

There is no trend in the carbon-to-hydrogen ratio with temperature, particle size, or flow rate, as seen in Fig. 7. The factorial effects of temperature, particle size, and flow rate were not calculated because of : the unusually low carbon-to-hydrogen ratio (0.94) of coal-pyrolysis liquid produced at $623 \mathrm{~K}\left(662^{\circ} \mathrm{F}\right)$ from 0.059 to $0.48 \mathrm{~cm}(-4+30$ mesh) coal with a purge-gas flow rate of $0.465 \mathrm{~L} / \mathrm{min}$. The small carbon-to-hydrogen ratio is likely due to water in the sample. Water must be removed from the sample tor accurate results. This was difficult to accomplish when less than $5 \mathrm{~g}$ of pyrolysis liquid was produced, as was the case for this run with an analyzed carbon-to-hydrogen ratio of 0.94 .

\subsection{Compatibility of Cual Liquids with Diesel Fuel}

The density, viscosity, and nitrogen content of coal liquids are comparable with diesel fuel. The liquids produced contained between 8 to $10 \mathrm{wt} \%$ water and oletins while diesel fuel cuntains 5 wt \% olefins, according the NMR analysis. NMR does not distinguish between water and olefins (11). The coal liquids have a 44 to $62 \%$ smaller aliphatic-toaromatic ratio than premium quality No. 2 diesel. The higher aromatic content could cause ignition or sooting problems when used as a substitute for or in a blend with diesel fuel. A higher aromatic content usually lowers the cetane rating. Diesel fuel should have a cetane number of at least 40 to function effectively as a fuel (14). The sulfur content of diesel fuel must be less than $0.5 \mathrm{wt} \%$ (ㅇ) . The sulfur content of one 
coal-pyrolysis sample was 1.35 wt \%. The sulfur must be removed or the pyrolysis liquid diluted with diesel fuel sufficiently to reduce the sulfur content to $0.5 \mathrm{wt} \%$ to be used in diesel fuel blends.

The maximum boiling point of diesel fuel is within the range of coal liquids produced at both low flow rates $(0.465 \mathrm{~L} / \mathrm{min})$ and high flow rates $(1.68 \mathrm{~L} / \mathrm{min})$. The reactor should be operated at the highest flow rate because the maximum boiling point of the product is comparable with diesel fuel; yield also increases with faster flow rates.

\subsection{Coal-Pyrolysis Material Balance}

A material balance accounted for $95 \%$ of the starting material and $74 \%$ of the volatiles at $723 \mathrm{~K}\left(842^{\circ} \mathrm{F}\right)$ at a purge-gas flow rate of $0.465 \mathrm{~L} / \mathrm{min}$, with $0.059-$ to-0.48-cm $(-4+30$ mesh) particles. The error was likely in determination of the composition of the residual gas. The gas sample was not analyzed until two days after it had been collected. because of equipment problems. Gas could have leaked and been replaced with air. This would increase the concentration of nitrogen in the sample and would result in a lower concentration of generated gas. The flow rate of gas leaving the reactor was measured only halfway through the run and was assumed constant throughout the run. Another possible source of error is the loss by accumulation of condensed material in the condenser and tube that connects the reactor and condenser.

\subsection{Properties of Coal-Pyrolysis Liquids Produced from Dean Seam \#3 Coal}

The yield [weight of coal liquids/weight of volatiles)(100\%)] of Dean Seam \#3 coal was $20 \%$ higher than Kentucky \#9 coal. Coal 1 iquids produced from Dean Seam \#3 coal had a density, viscosity, and aliphatic-to-aromatic ratio comparable with coal liquids produced from Kentucky \#9 coal, and the carbon-to-hydrogen ratio was closer to that for diesel fuel. For these reasons, Dean Seam \#3 coal liquids should be tested in diesel engines.

\subsection{Physical-Property Correlations}

Simulated distillation curves of the condensed volatile matter from the coal retort were obtained from a Shimadzu GCGA gas chromatograph. The simulated distillation curves were separated into fractions by mathematically dividing the curve at $50-K$ intervals from tabulated data. Each fraction of similar boiling point was considered a pseudocomponent, i.e., a blend of pure components having similar physical properties. The arithmetic-mean boiling point of each pseudocomponent was used to predict the characterization parameters of coal liquids: specific gravity, critical temperature, and critical pressure. 
The API gravity of each psuedocomponent was predicted with the Prudich correlations (8), tabulated in Table 9, from the pseudocomponent average boiling point $\overline{\mathrm{T}}_{\mathrm{b}}$. The API gravity is related to the specific gravity by $(\underline{14})$ :

$$
\mathrm{API}=\frac{141.5}{\mathrm{Sp} . \mathrm{Gr} .}-131.5
$$

in which Sp. Gr. is the specific gravity at $289 \mathrm{~K}\left(60^{\circ} \mathrm{F}\right)$. The predicted specific gravity of the pseudocomponents ranged from 0.822 to 1.06 . The measured values for the mixture of pseudocomponents ranged from 0.93 to 0.96 .

Table 9. Prudich Correlations

API grav $=\frac{141.5}{0.56+0.00102 T_{b}}-131.5$

for $200^{\circ} \mathrm{F}<\mathrm{T}_{\mathrm{b}}<400^{\circ} \mathrm{F}$ and $\mathrm{T}_{\mathrm{b}}=$ average boiling point, ${ }^{\circ} \mathrm{R}$.

API grav $=14.678$

for $400^{\circ} \mathrm{F}<\mathrm{T}_{\mathrm{b}}<475^{\circ} \mathrm{F}$

API grav $=\frac{141.5}{0.764710 .000428 T_{b}}-131.5$

for $475^{\circ} \mathrm{F}<\mathrm{T}_{\mathrm{b}}<900^{\circ} \mathrm{F}$

The critical properties of the pseudocomponents were based on the Wilsull currelations (21), which relate the characterization parameters of coal liquids to boiling point and spccific gravity. The Wilson equatiuis are presented in Table 10.

The predicted characterization parameters of the pseudocomponents for coa 1-pyrolysis liquids obtained at $723 \mathrm{~K}$ with $0.059-$ to- $0.48-\mathrm{cm}(-4+30$ mesh) particles and a nitrogen flow rate of $0.465 \mathrm{~L} / \mathrm{min}$ are tabulated in Table 11. These properties are tabulated in Appendix 9.7 for other coalliquid samples. The critical properties of the coal liquids were not determined experimentally, hence there is no basis for comparison. 
Watson characterization parameter:

$$
\begin{aligned}
K_{W} & =\left(T_{b}\right)^{1 / 3} / \mathrm{Sp} . \mathrm{Gr} . \\
T_{b} & =\text { average boiling point, }{ }^{\circ} \mathrm{R}
\end{aligned}
$$

Molecular weight MW:

$$
\ln (M W)=-10.9419+2.3333 \cdot \ln T_{b}-\ln \mathrm{Sp} . \mathrm{Gr}
$$

Critical pressure $P_{C}$ :

$$
\begin{aligned}
& \log \left(P_{c}\right)=2.22066-0.05445 K_{w}+3.12579\left(1-\frac{T_{b}}{T_{c}}\right) \\
& P_{c} \text { is in psia. }
\end{aligned}
$$

Critical temperature $T_{c}$ :

$$
\log \left(T_{C}\right)=1.1569+0.38882 \log (\mathrm{Sp} \cdot \mathrm{Gr} .)+0.66709 \log \left(T_{b}\right)
$$

Acentric factor $\omega$ :

$$
\begin{aligned}
& \omega=\left[\ln \left(\frac{14.7}{P_{C}}\right)-f_{0}\right] / f_{1} \\
& f_{0}=5.92714-\frac{6.09648}{T_{R}}-1.28862 \ln T_{R}+0.169347\left(T_{R}\right)^{6} \\
& f_{1}=15.2518-\frac{15.6875}{T_{R}}-13.4721 \ln T_{R}+0.43577\left(T_{R}\right)^{6}
\end{aligned}
$$

Critical compressibility $z_{c}$ :

$$
z_{c}=\frac{1}{1.28 w+3.41}
$$

Critical volume $V_{c}$ :

$$
v_{c}=\frac{Z_{c} T_{c} 670.14}{P_{c}} \mathrm{~cm}^{3} / \mathrm{mol}
$$

Heat capacity $C_{p}\left(B t u / 1 b-{ }^{\circ} F\right)$ :

$$
\begin{aligned}
& \text { constants for } C_{p}-a \neq b T \\
& a=\left(0.465+0.0136 K_{w}\right)(0.4949-0.02479 \mathrm{sp.Gr} .) \\
& b=\left(0.465+0.0436 K_{w}\right)(0.8117-0.3672 \mathrm{Sp} . \mathrm{Gr} .) \times 10^{-3}
\end{aligned}
$$


Table 11. Pseudocomponen: Properties for Kentucky \#9 Coal

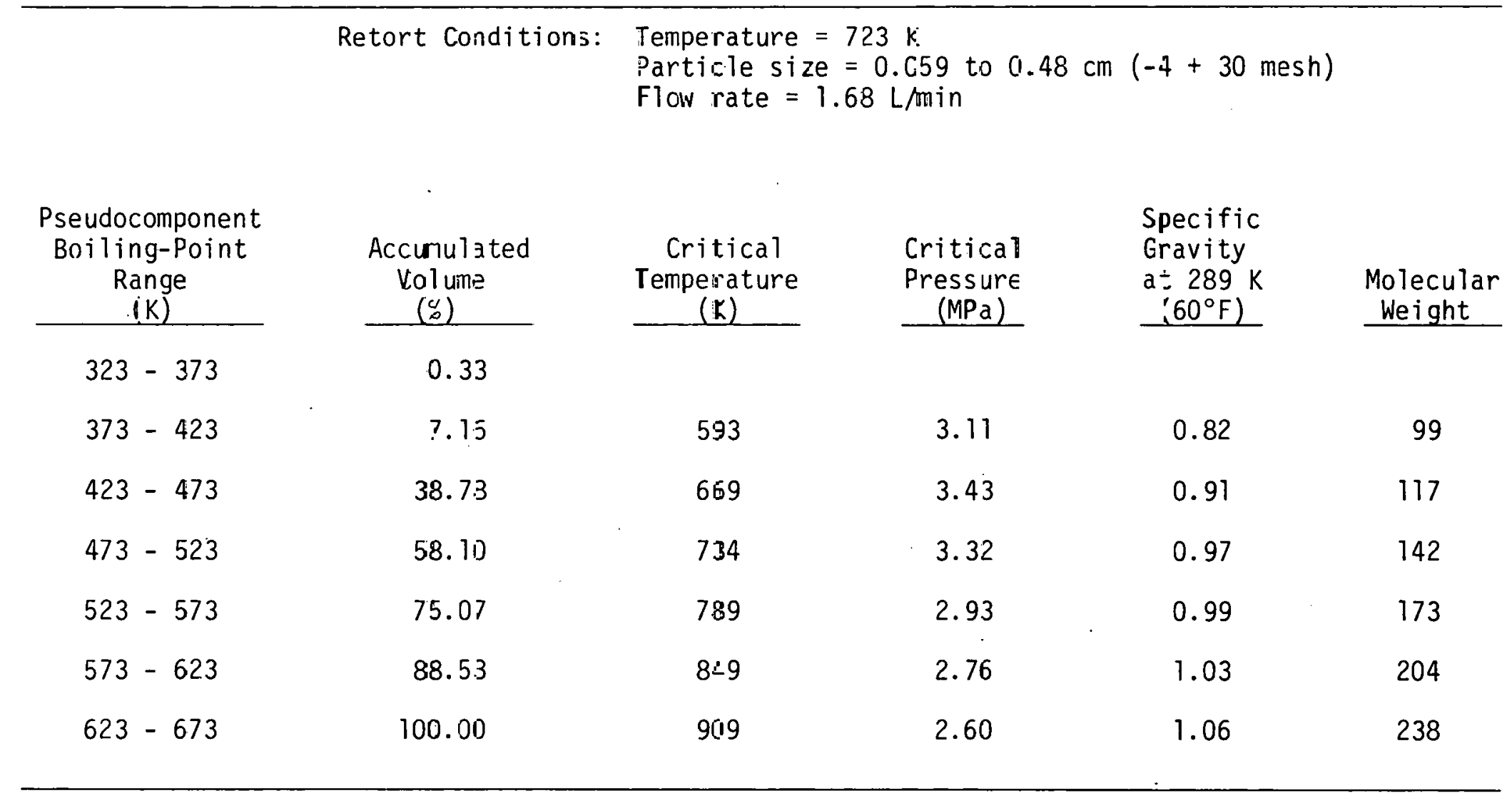




\section{CONCLUSIONS}

1. Coal-liquid yield increased with higher pyrolysis temperature, over the range studied of 623 to $723 \mathrm{~K}$.

2. Greater yields of coal liquids were collected as purge-gas flow rate was increased from 0.465 to $1.68 \mathrm{~L} / \mathrm{min}$.

3. The viscosity and density of coal-pyrolysis liquids produced at $723 \mathrm{~K}$, and the maximum boiling point of coal liquids produced at a nitrogen-purge-gas flow rate of $0.465 \mathrm{~L} / \mathrm{min}$, were comparable with those of diesel fuel. At this higher temperature, the aliphatic to-aromatic ratio of coal-pyrolysis liquids was lower and the carbon-to-hydrogen ratio was higher than those of diesel fuel.

4. Exposure to ultraviolet light increased the aliphatic-to-aromatic ratio and widened the final boiling point range of coal-pyrolysis liquids.

\section{RECOMMENDATIONS}

1. The compatibility of coal-pyrolysis liquid and diesel fuel should be determined by observing whether precipitates or emulsions are found when the two liquids are blended.

2. Blends of diesel fuel and coal-pyrolysis liquids produced from Kentucky \#9 and Dean Seam \#3 coal at $723 \mathrm{~K}$ at a purge-gas flow rate between 0.465 and $1.68 \mathrm{~L} / \mathrm{min}$ should be tested in diesel engines as a final evaluation of their utility in an unrefined state.

3. The maximum operating temperature of the pyrolysis reactor which maintains coal-liquid quality should be determined.

\section{ACKNOWLEDGMENT}

We thank Ron Graves and Van Brantley for their instruction on the use of the rnal-pyrolysis equipment. We especially thank Joe Stewart, Jr., for the speed in which he provided the chemical analyses, and Jim Attrill and C.. Ho for their valuable aid in helping with the chemical analyses essential to this work. 


\section{APPENDIX}

\subsection{Methods of Determining Aliphatic-to-Aromatic Ratio}

Since NMR does not give an accurate measurement of the aliphatic-toaromatic ratio, column chromatography was tried. The column was made from Sephadex LH-20 gel in isopropanol. The coal-pyrolysis liquid was added to the top of the column and washed with isopropanol. Radioactive ${ }^{14} \mathrm{C}$ beta-emitting hexadecane was added to trace the aliphatics. An additional $300 \mathrm{ml}$ of isopropanol was added, and the effluent was collected in 100-, 50-, 2-to-25-, and 5-to-10-ml fractions. The samples were counted for beta emission to determine which fractions were aliphatic, after which about $500 \mathrm{ml}$ of benzene was added to the column to remove aromatics. The aliphatic fractions were combined, and the isopropanol evaporated with a rotoevaporator. Solvent was evaporated from the aromatic fractions similarly. The solvent-free samples were weighed to determine the fractions of aliphatics and aromatics in the pyrolysis liquids. Only $85 \mathrm{wt} \%$ of the coal liquid was recovered because of losses by evaporation. The aliphatic-to-aromatic ratio of the aliphatic and aromatic fractions was determined with NMR to check the separation. The aliphatic-to-aromatic ratio of the coal liquid was 2.8; that of the aliphatic fraction was 4.8 . Column chromatography is therefore not suitable for determining the aliphatic-to-aromatic ratio of pyrolysis liquids (10).

\subsection{Calibration of Pycnometer}

The densities of water, methanol, and acetone from our experimental

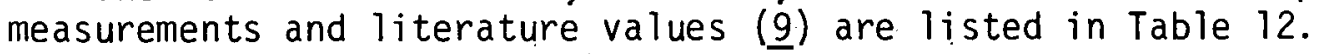

Table 12. Pycnometer Calibration

\begin{tabular}{|c|c|c|c|}
\hline Liquid & $\begin{array}{c}\text { Experimentally } \\
\text { Determined } \\
\text { Density } \\
(\mathrm{g} / \mathrm{ml}) \\
\end{array}$ & $\begin{array}{r}\text { Literature }(\underline{9}) \\
\text { Density } \\
(\mathrm{g} / \mathrm{ml}) \\
\end{array}$ & $\begin{array}{c}\text { Ratio of } \\
\text { Experimental to } \\
\text { Literature } \\
\text { Density } \\
\end{array}$ \\
\hline Acetonne & $0.7 n \cap\left(24.6^{\circ} \mathrm{C}\right)$ & $0.759\left(25^{\circ} \mathrm{C}\right)$ & 0.922 \\
\hline Methanol & $0.703\left(23.8^{\circ} \mathrm{C}\right)$ & $0.786\left(24^{\circ} \mathrm{C}\right)$ & 0.894 \\
\hline Water & $0.902\left(26.4^{\circ} \mathrm{C}\right)$ & $0.997\left(26.4^{\circ} \mathrm{C}\right)$ & 0.905 \\
\hline
\end{tabular}

The average ratio of experimental density to the density reported in the literature was $0.907 \pm 0.015$. Therefore, all density measurements were divided by 0.907 to obtain the true density. 


\subsection{Particle-Size Distribution}

The particle-size distribution of the coal was measured by placing between 150 and $250 \mathrm{~g}$ of coal on top of a stack of sieve pans. The stack was electrically shaken for $4 \mathrm{~min}$, and the amount of material retained on each sieve tray was weighed. The particle-size distribution is given in Table 13.

Table 13. Particle-Size Distribution

\begin{tabular}{|c|c|c|c|c|}
\hline \multirow[b]{2}{*}{$\begin{array}{l}\text { Sieve } \\
\text { Size } \\
\end{array}$} & \multirow[b]{2}{*}{$\begin{array}{l}\text { Opening } \\
(\mathrm{cm}) \\
\end{array}$} & \multicolumn{3}{|c|}{ Cumulative wt $\%$ Retained } \\
\hline & & $\begin{array}{l}\text { Kentucky \#9 } \\
\text { Large Size }\end{array}$ & $\begin{array}{l}\text { Kentucky \#9 } \\
\text { Small Size } \\
\end{array}$ & Dean Seam \#3 \\
\hline 6 & 0.336 & 62.0 & & 45.0 \\
\hline 16 & 0.119 & 99.2 & 54.6 & 90.6 \\
\hline 30 & 0.059 & 99.3 & 98.2 & 99.1 \\
\hline 100 & 0.015 & 99.3 & 99.5 & 99.4 \\
\hline Pan & & 100 & 100 & 100 \\
\hline Top Size & & $0.48 \mathrm{~cm}$ (4 mesh) & $0.2 \mathrm{~cm}(10$ mesh $)$ & $0.48 \mathrm{~cm}$ (4 mesh \\
\hline
\end{tabular}

\subsection{Simulated Distillation Curves}

The simulated distillation curves constructed for each of the coal liquids and diesel fuel are shown in Figs. 8 through 21. 


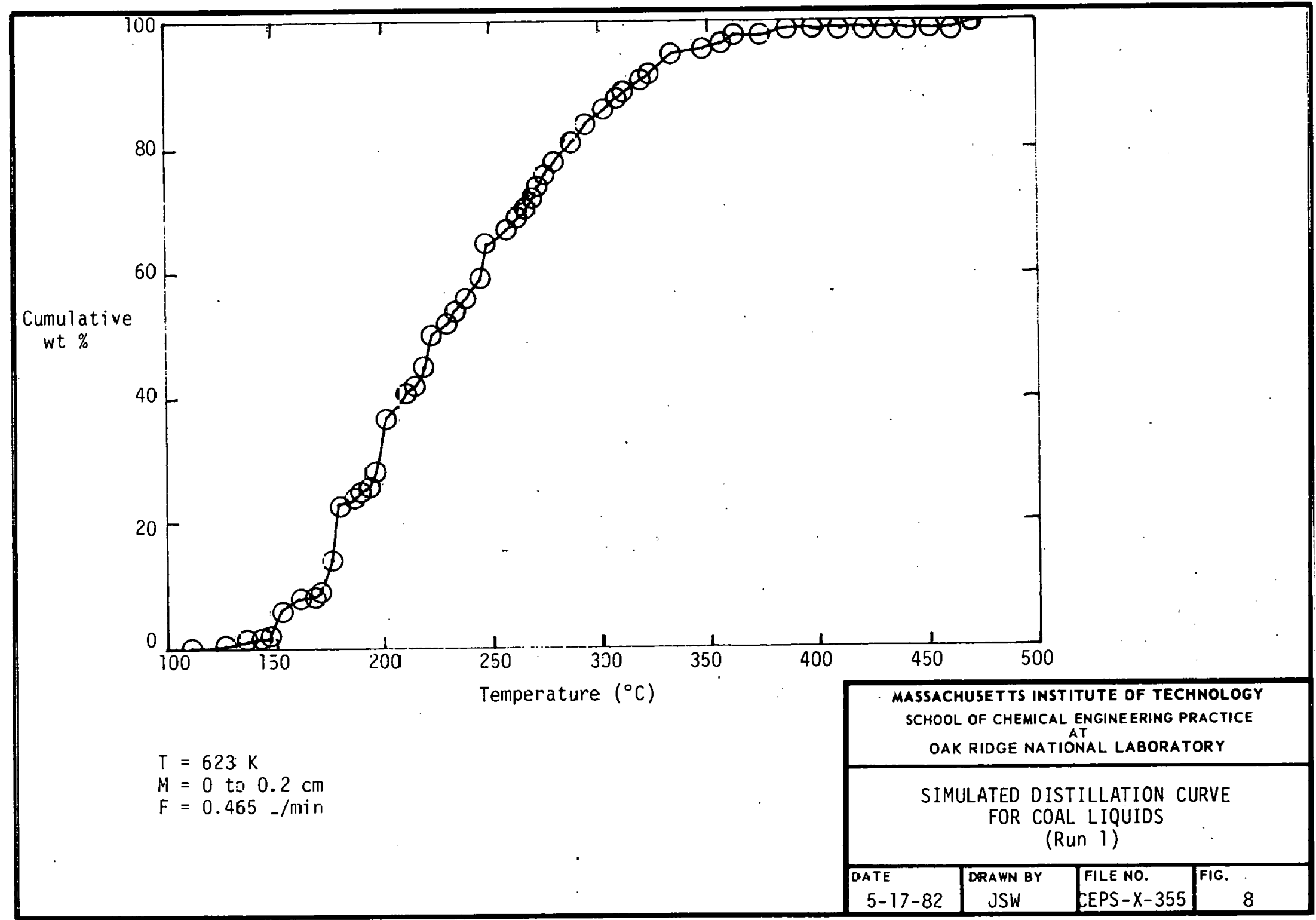




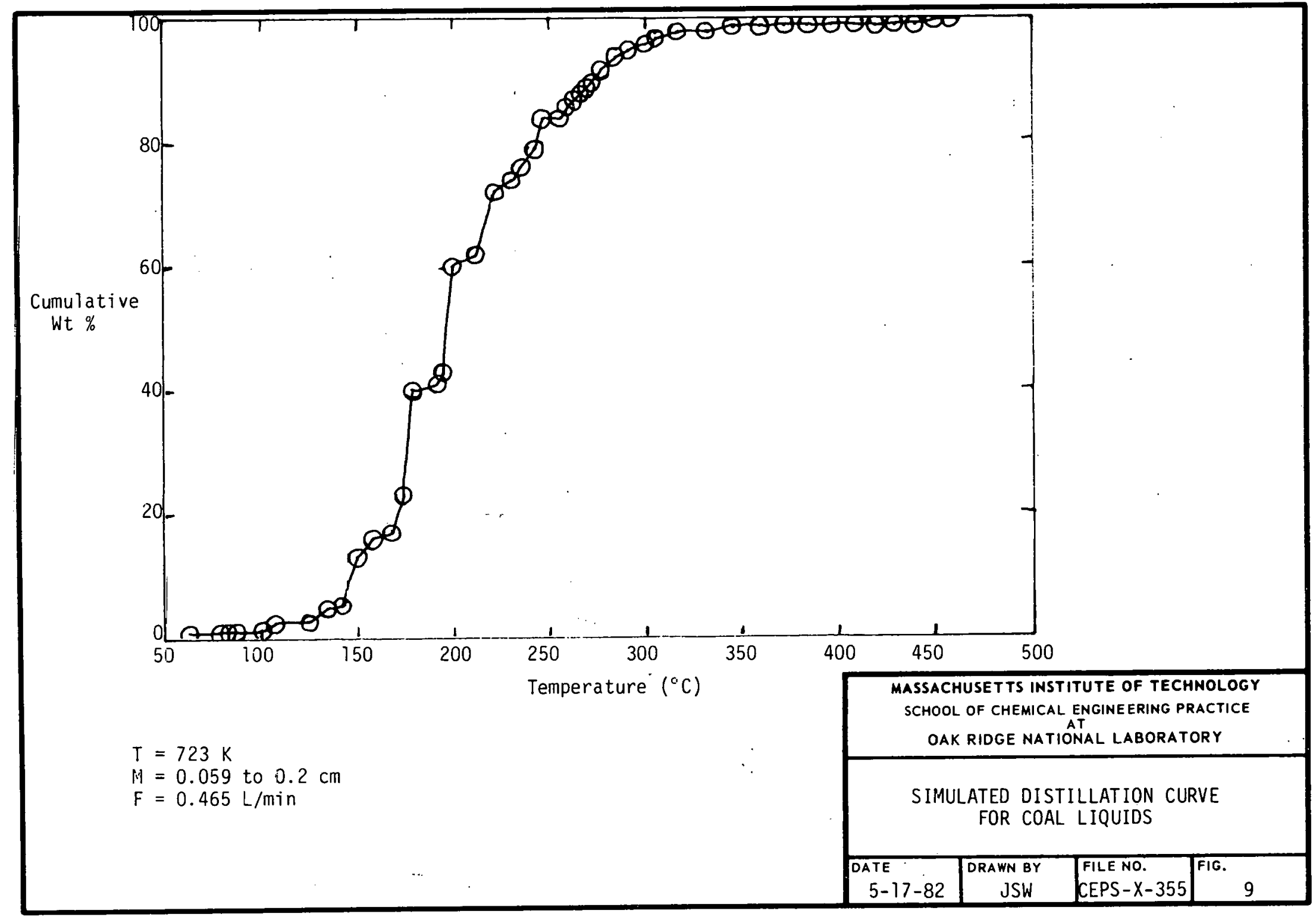




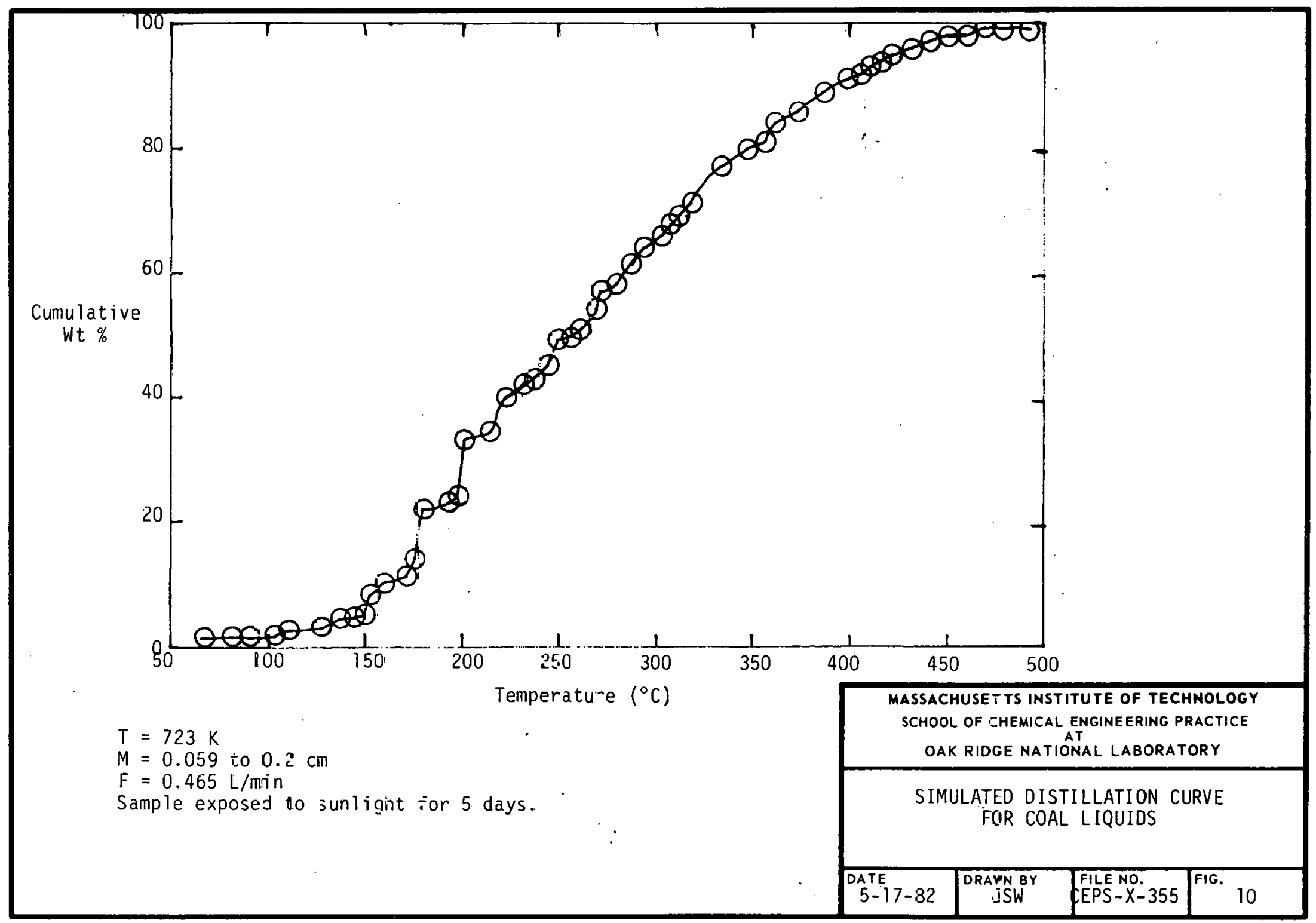




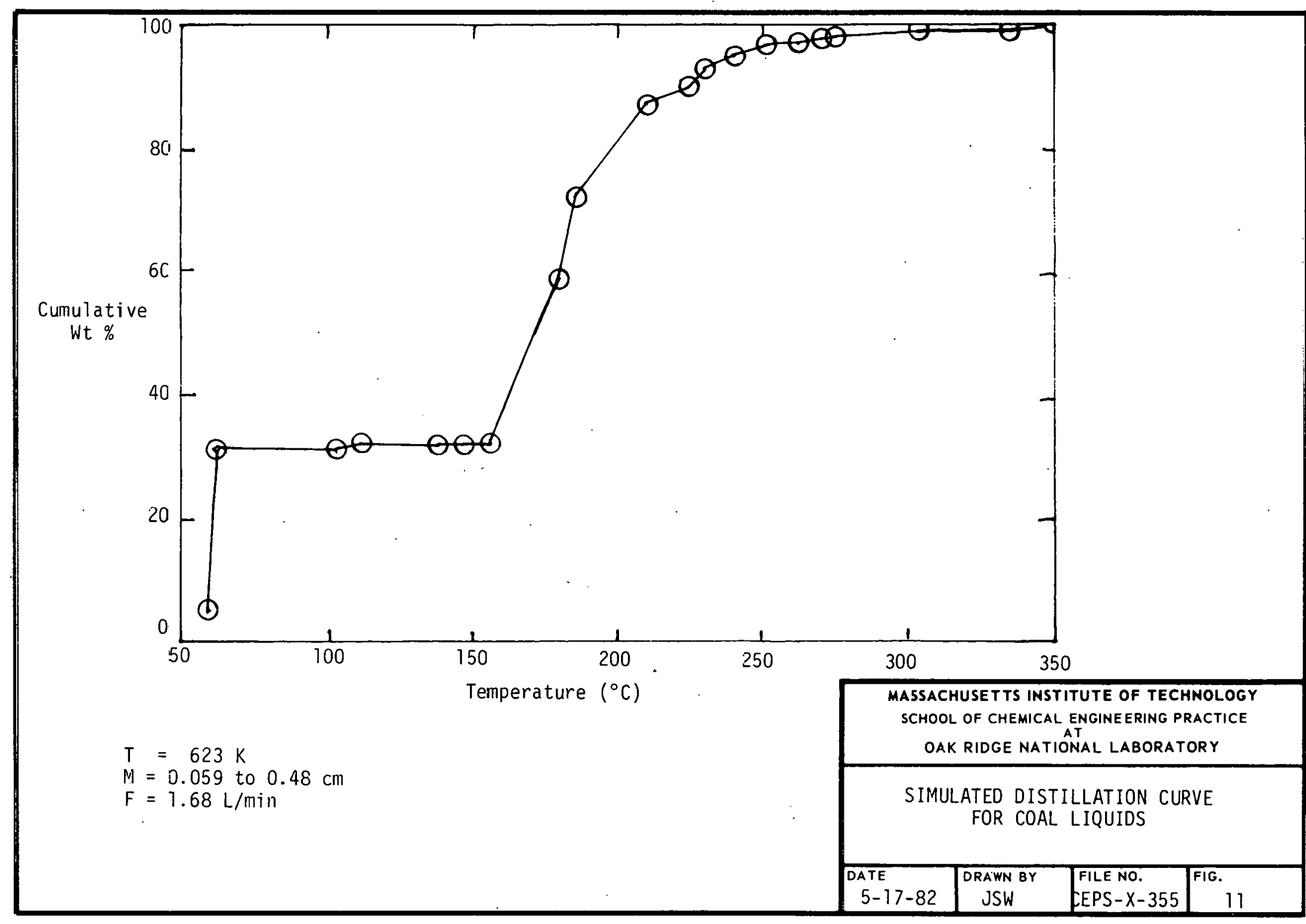




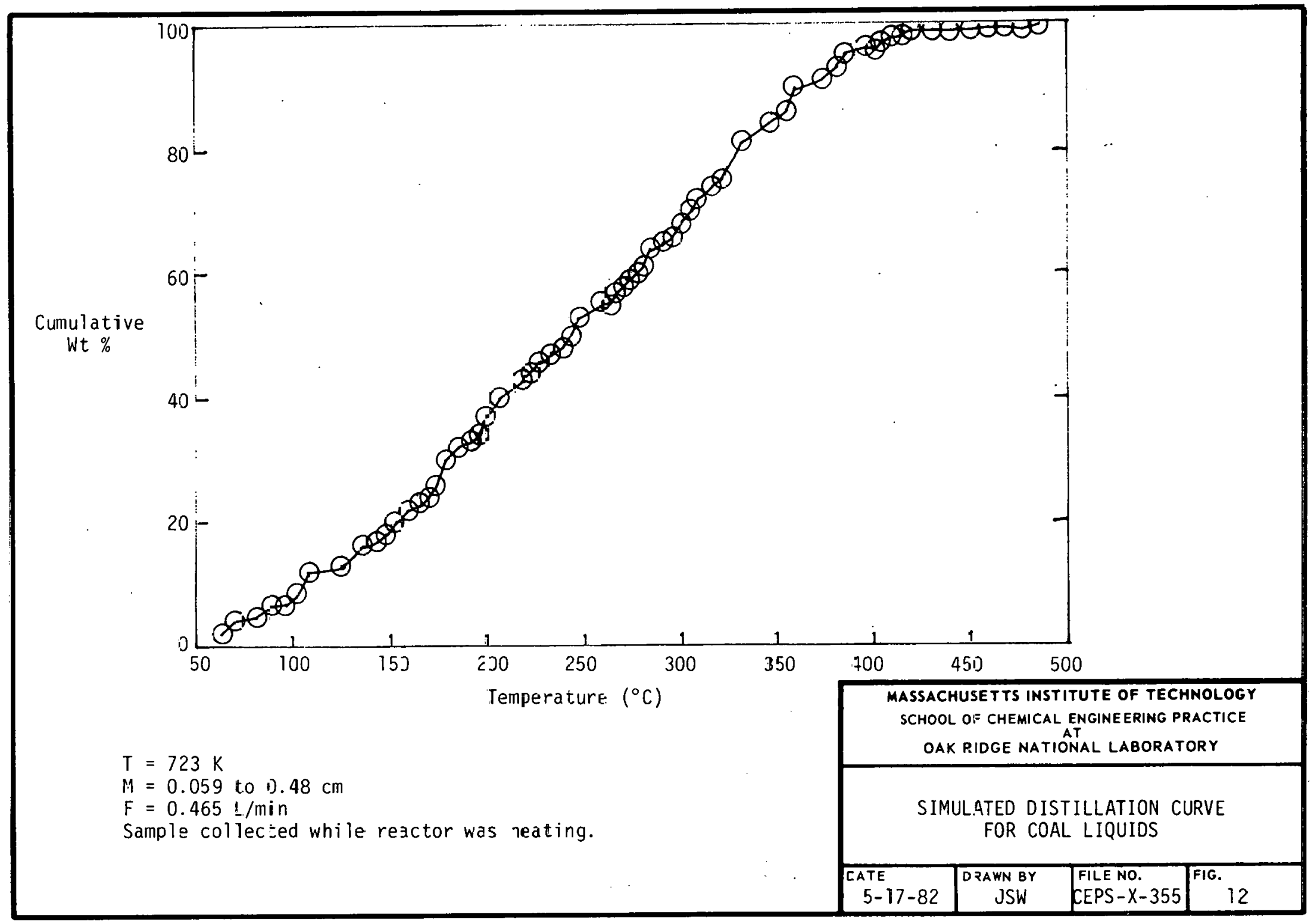




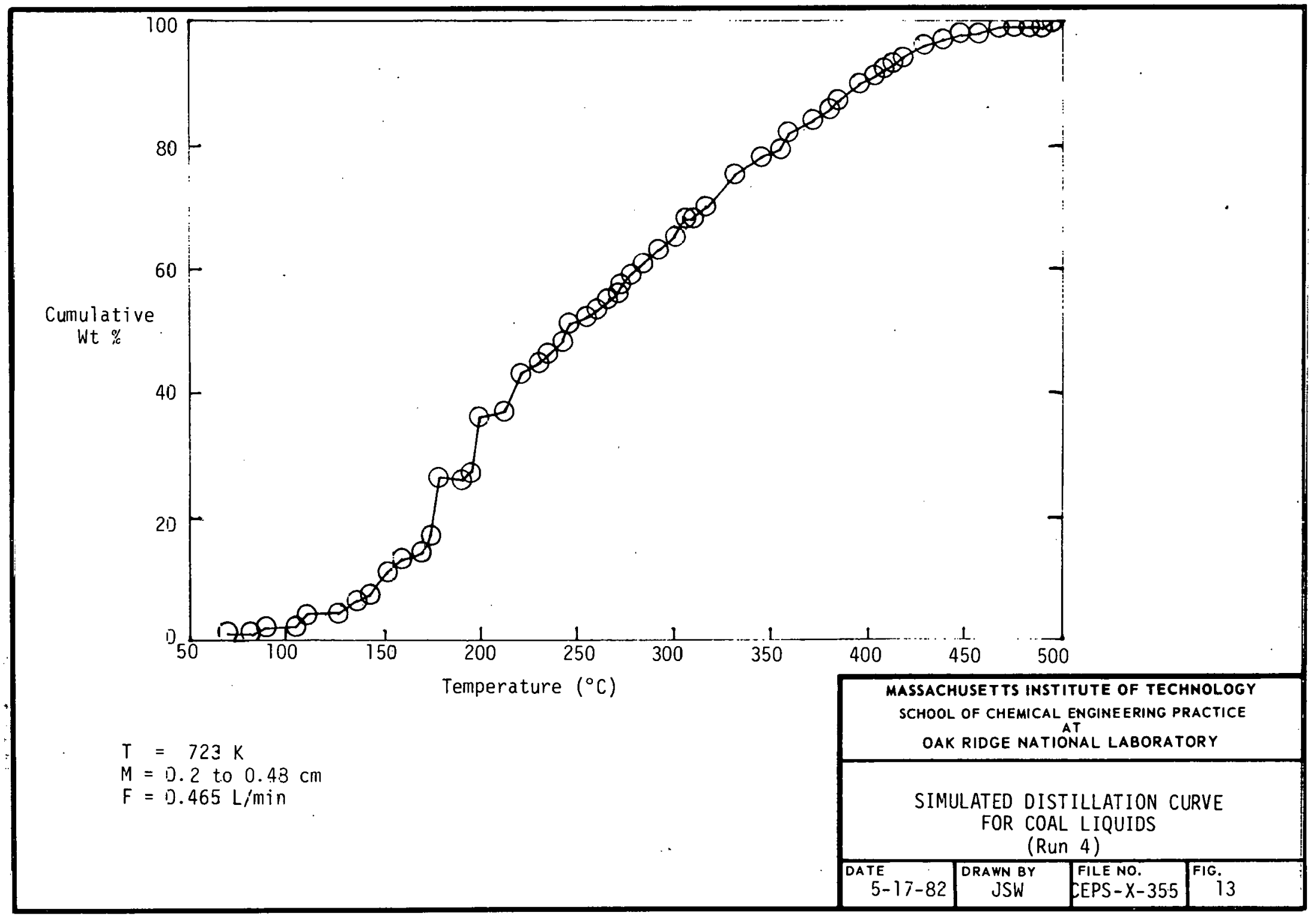




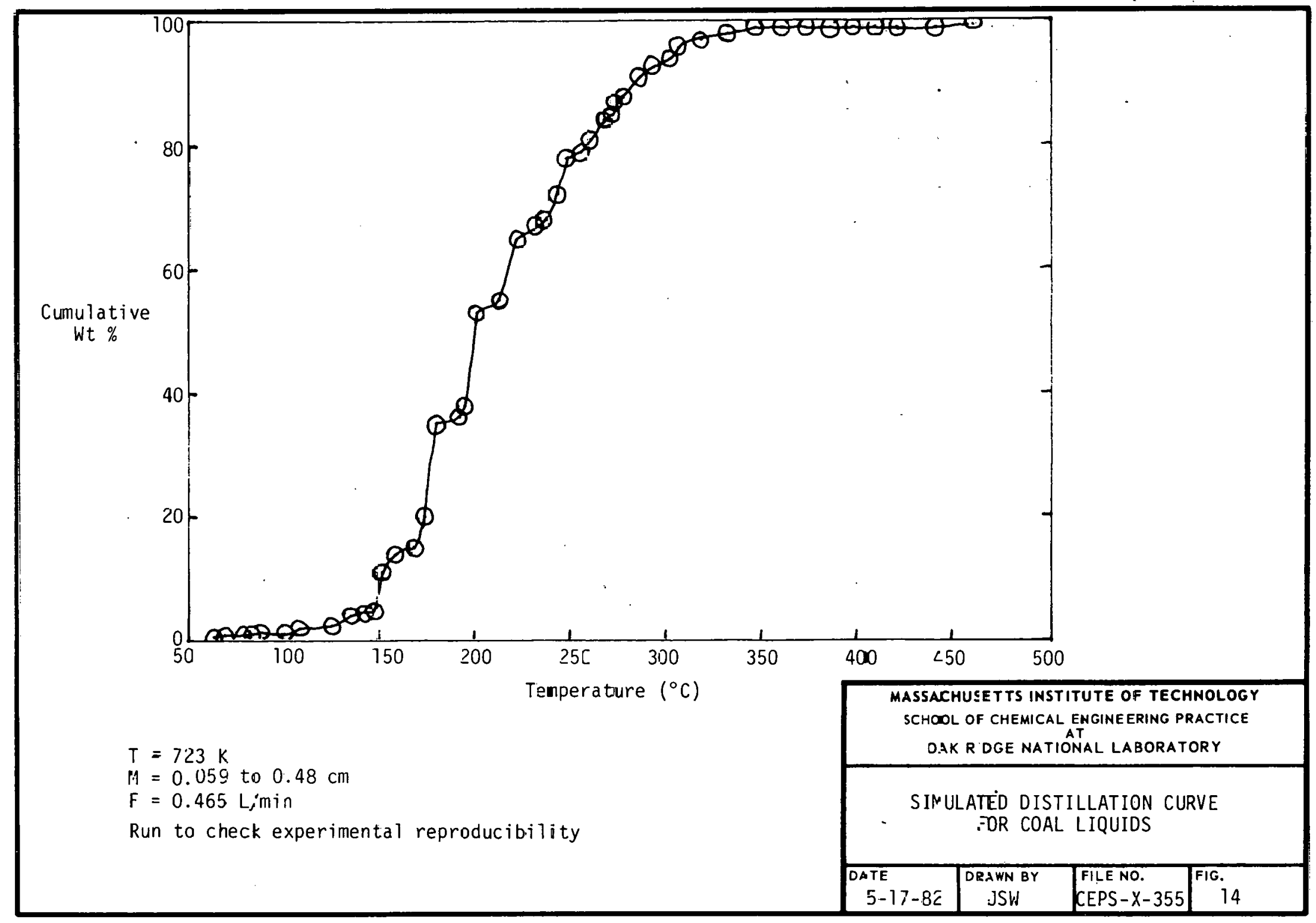




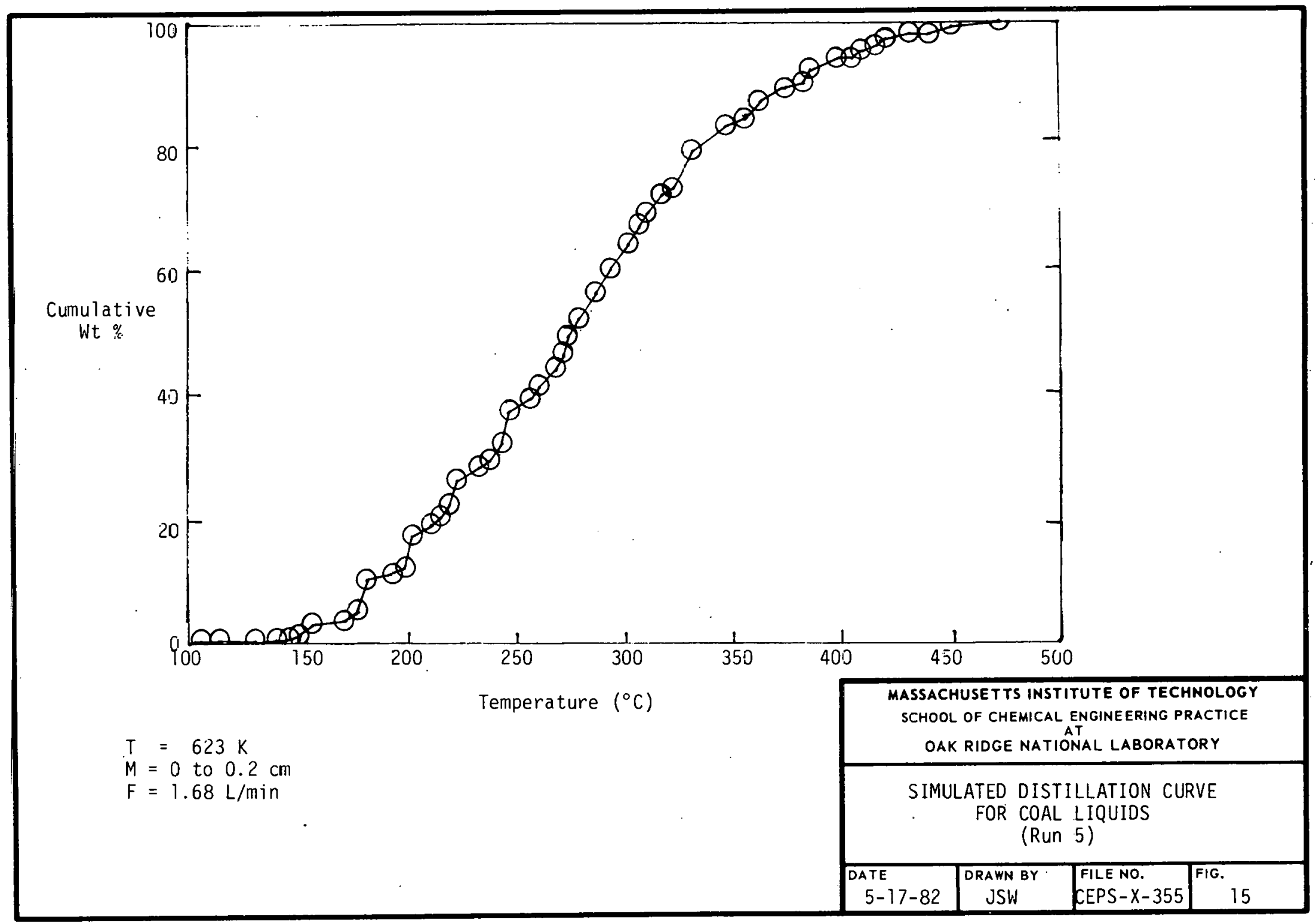




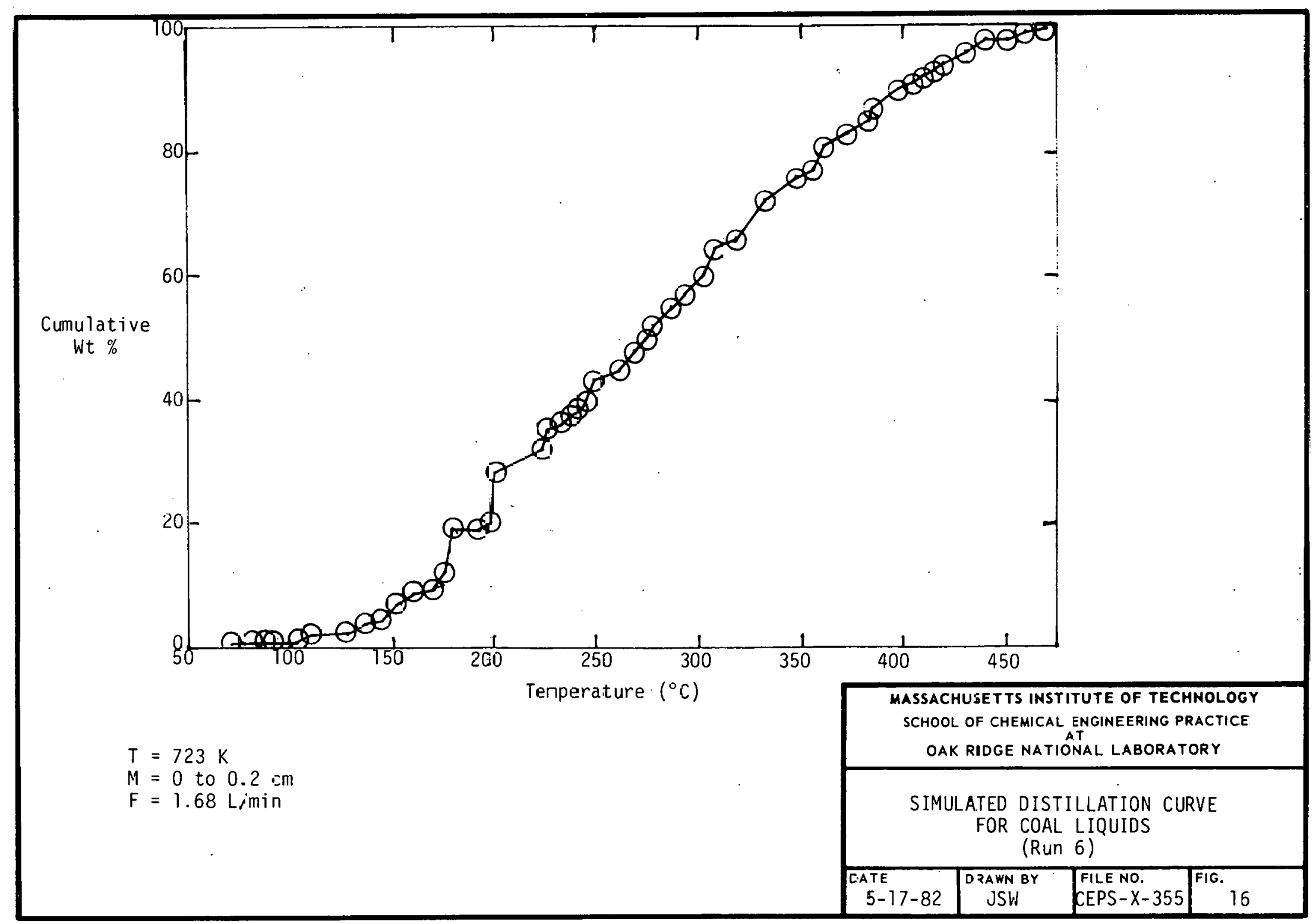




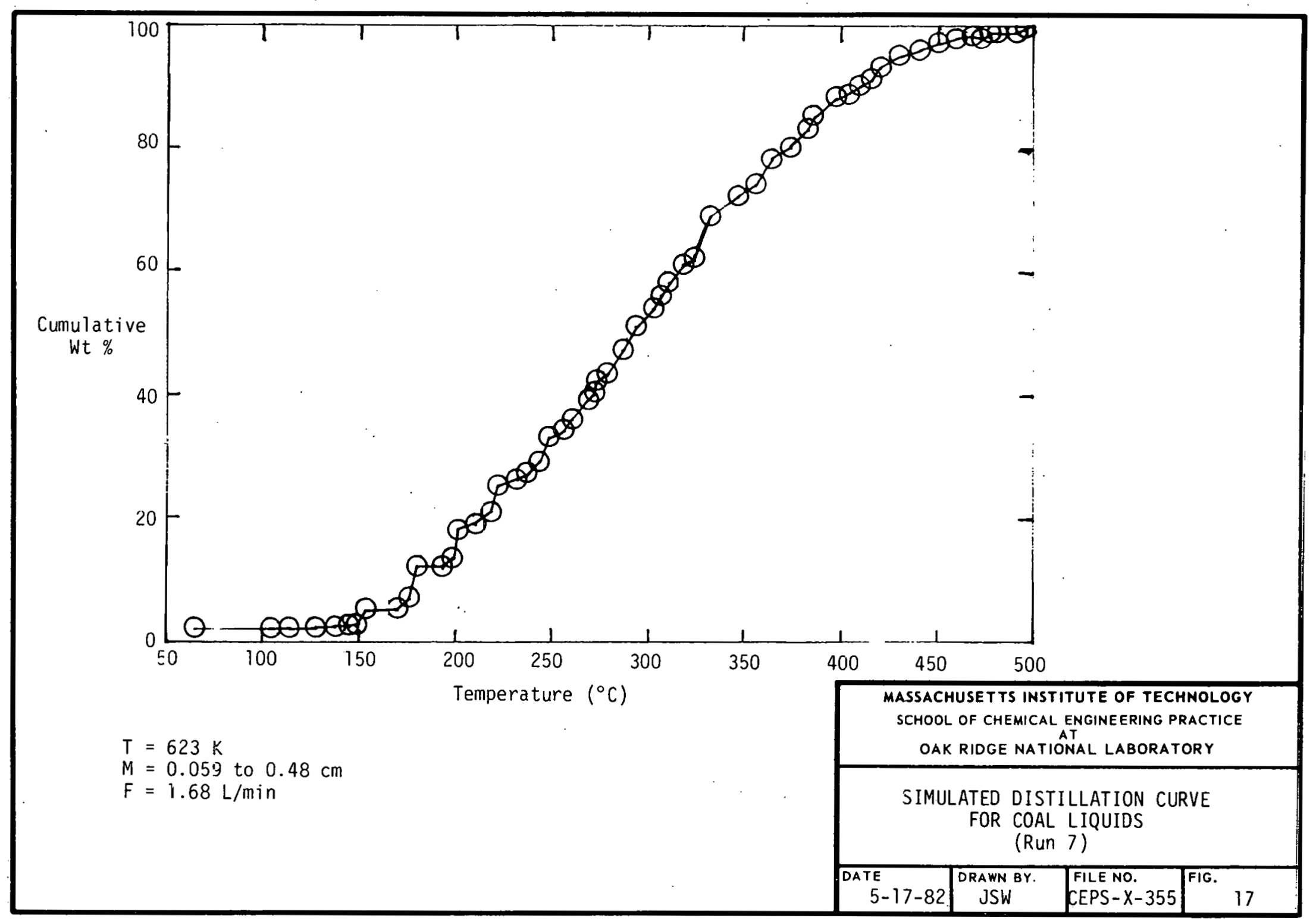




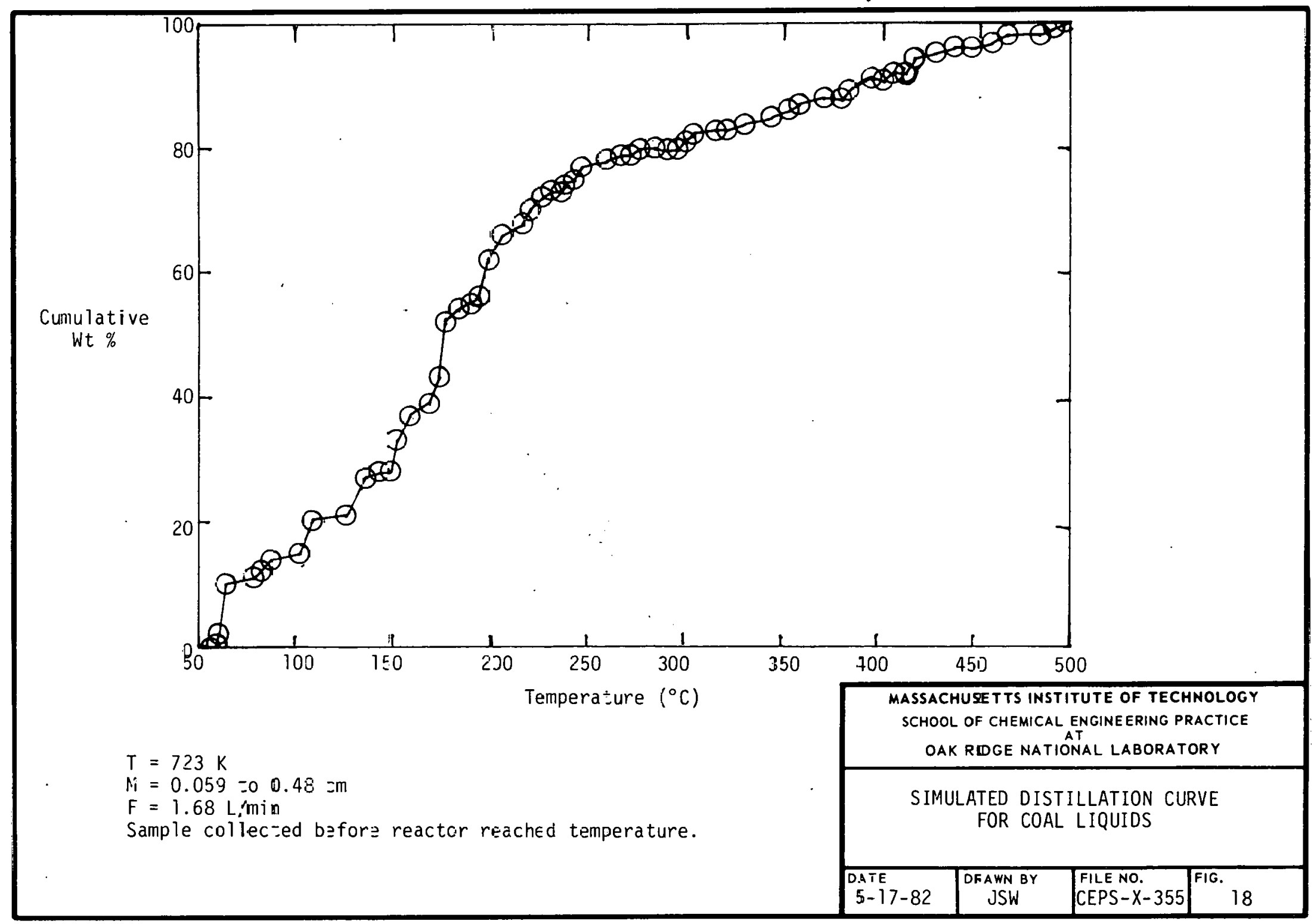




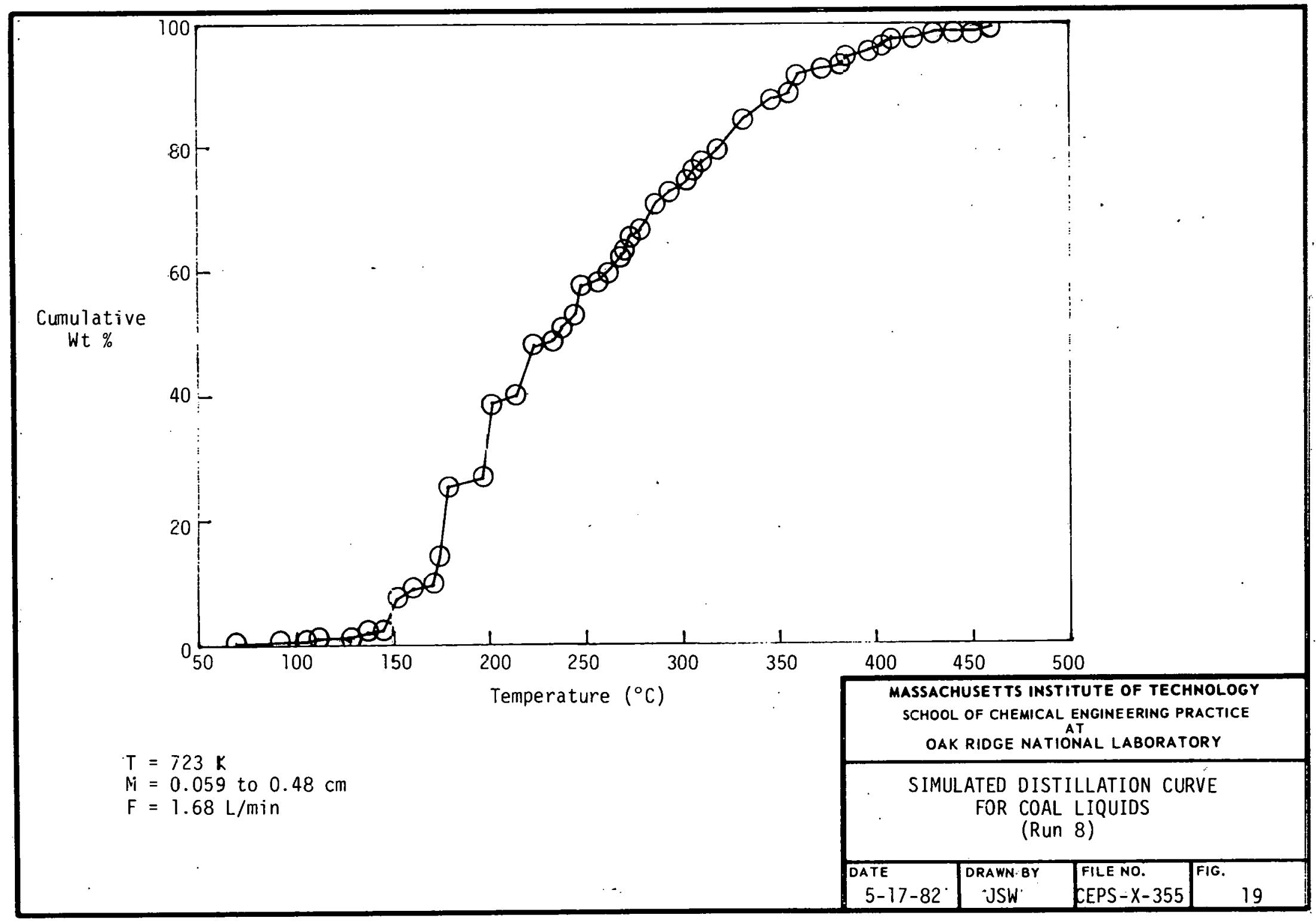




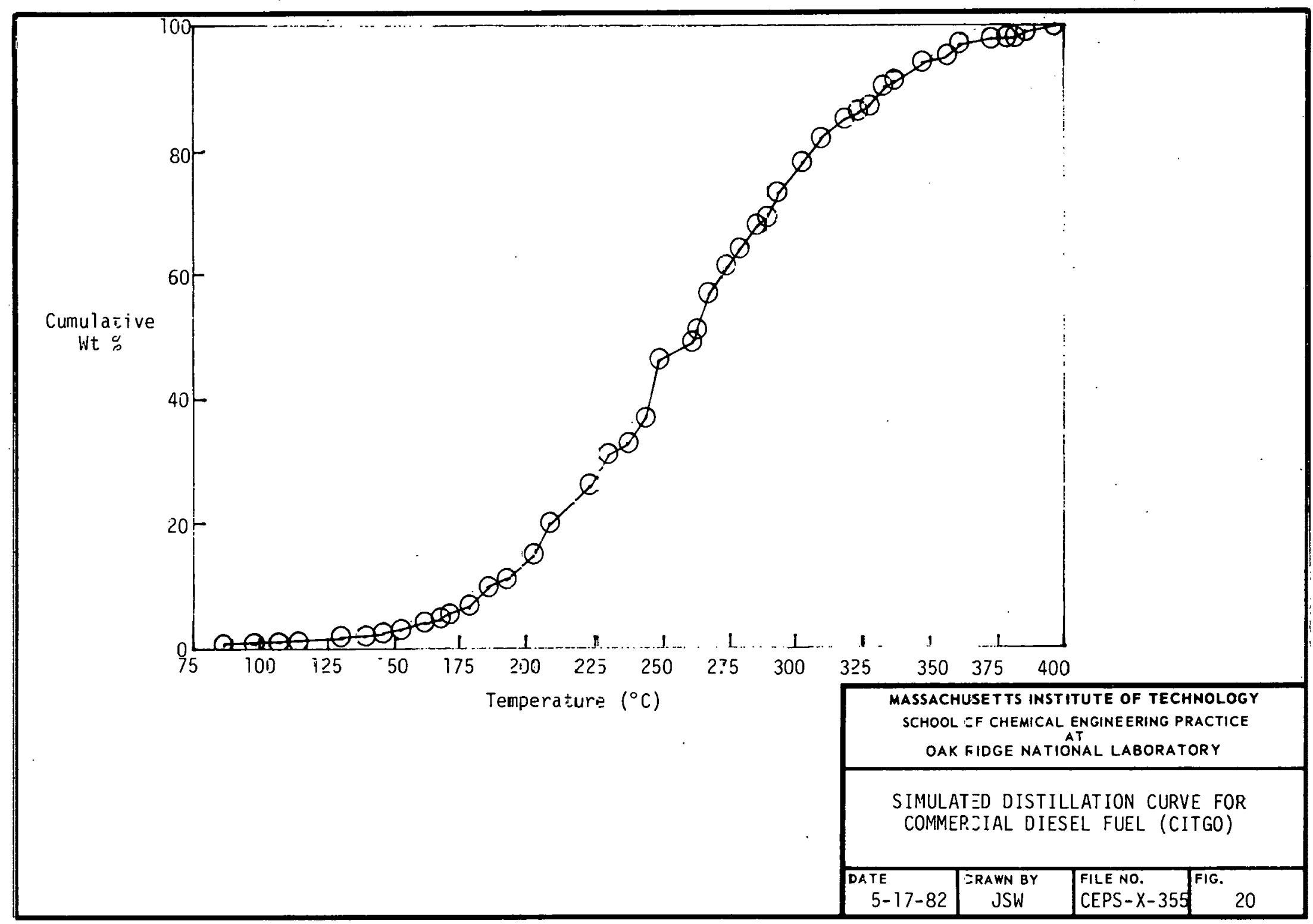




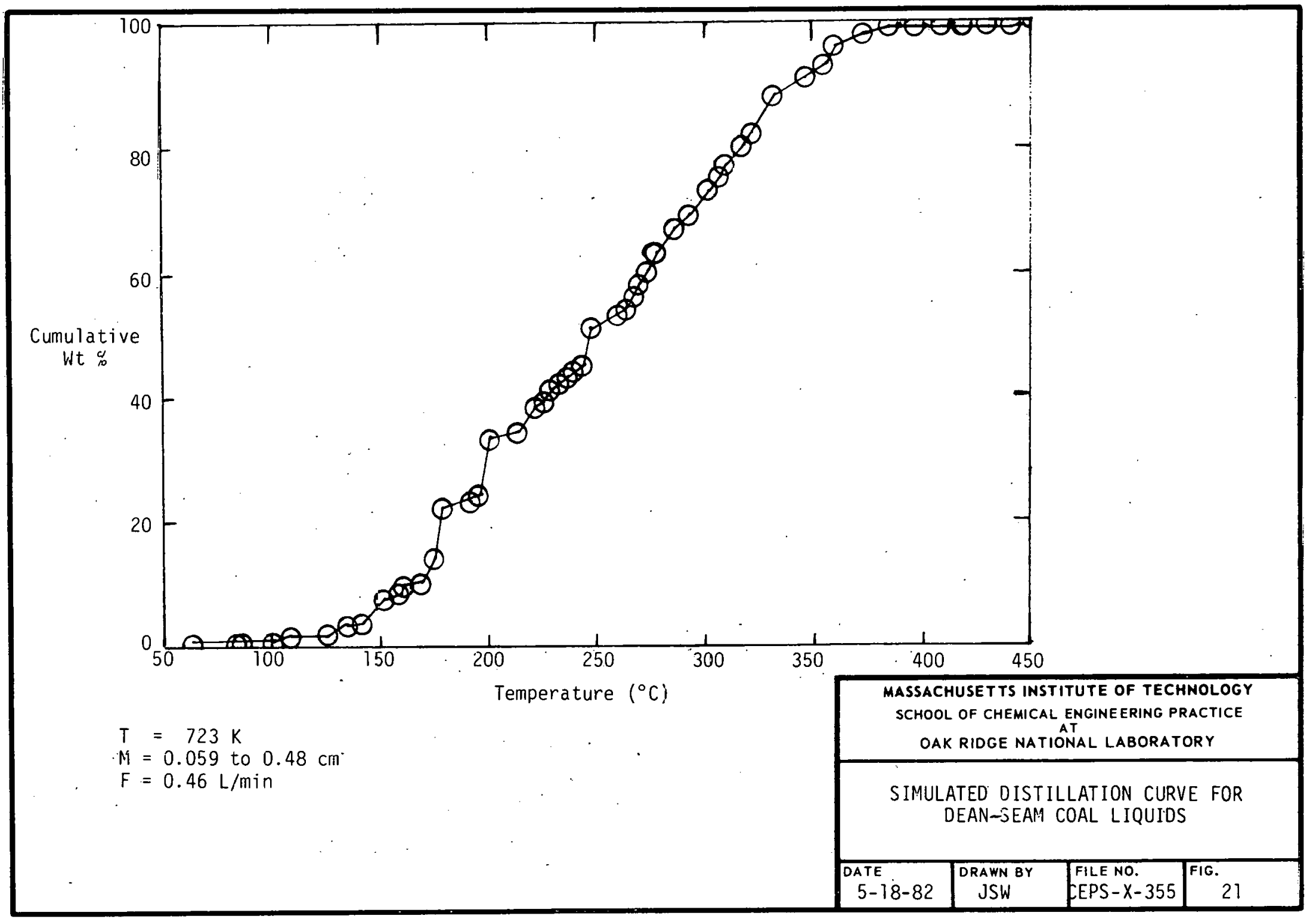

\pm . 


\subsection{Weight of Coal Liquids and Water Produced}

The weight of coal liquid and water, temperature overshoot, and time of temperature overshoot are tabulated in Table 14. The temperature overshoot is the difference between the maximum and the desired temperature, before the reactor assumed steady-state operation.

Table 14. Experimental Conditions

\begin{tabular}{|c|c|c|c|c|c|c|}
\hline Run & $\begin{array}{l}\text { Coal } \\
\text { Charged } \\
\text { to } \\
\text { Reactor } \\
\cdot(\mathrm{g}) \\
\end{array}$ & $\begin{array}{l}\text { Char } \\
\text { (g) }\end{array}$ & $\begin{array}{c}\text { Collected } \\
\text { Coal } \\
\text { Liquids } \\
(g) \\
\end{array}$ & $\begin{array}{c}\text { Collected } \\
\text { Water } \\
(\mathrm{g}) \\
\end{array}$ & $\begin{array}{c}\text { Temperature } \\
\text { Overshoot } \\
(\mathrm{K}) \\
\end{array}$ & $\begin{array}{l}\text { Time of } \\
\text { Temperature } \\
\text { Overshoot } \\
\text { (min) }\end{array}$ \\
\hline 1 & 640.0 & 588.6 & 1.7 & 39.0 & 0 & - \\
\hline 2 & 640.0 & 541.6 & 13.0 & 52.4 & 17 & 10 \\
\hline 3 & 640.6 & 574.6 & 3.3 & 43.4 & 25 & 50 \\
\hline 4 & 640.0 & 525.2 & 12.9 & 48.3 & 0 & 0 \\
\hline 5 & 640.0 & 581.4 & 2.75 & 33.5 & 0 & 0 \\
\hline 6 & 6 & 524.0 & 29.1 & 37.6 & 0 & 0 \\
\hline 7 & 640.0 & 577.8 & 6.7 & 66.1 & 14 & 20 \\
\hline 8 & 681.0 & 564.4 & 24.6 & 47.2 & 14 & 10 \\
\hline
\end{tabular}

The data from an attempt to reproduce Run 4 were discarded because the temperature overshoot was greater than $28 \mathrm{~K}$ (temperature recorder went off scale), and the time of the temperature overshoot was $140 \mathrm{~min}$.

\subsection{Yates' Älgorithm}

Yates' algorithm (1) was used to calculate the main effects and interactions between variables for the factorial experiments. The runs must be arranged in a standard order: the first column of the design matrix must alternate between the two variable levels, the second column must consist of alternating pairs of the two variable levels, and the third column consists of four entries of one variable level followed by four entries of the other level, as listed in: Table 15. The yield of each set of run 
conditions is given in the fourth column. The first four entries of the fifth, sixth, and seventh columns are obtained by adding successive pairs of the previous columns; and the second four entries are obtained by subtracting the top number from the bottom number of each pair in the previous column, as shown in the table. The eighth column is obtained by dividing all entries in the seventh column, but the first, by 4 . The first entry is divided by 8 . The effects and interactions between variables are tabulated in column 8.

Table 15. Yates' Algorithm for Calculating Effect on Yield

\begin{tabular}{|c|c|c|c|c|c|c|c|c|}
\hline $\begin{array}{l}1 \\
I\end{array}$ & $\begin{array}{l}2 \\
\underline{M}\end{array}$ & $\begin{array}{l}3 \\
\underline{F}\end{array}$ & $\begin{array}{c}4 \\
\text { Yield } \\
\end{array}$ & 5 & 6 & 7 & $\begin{array}{c}8 \\
\text { Effect } \\
\end{array}$ & \\
\hline- & - & - & 0.68 & 5.85 & 12.47 & 4.66 & 5.8 & average \\
\hline+ & - & - & 5.17 & 6.62 & 24.83 & 6.40 & 8.7 & $T$ \\
\hline- & + & - & 1.35 & 12.66 & 8.41 & 0.07 & 2.4 & M \\
\hline+ & + & - & 5.27 & 12.17 & 17.19 & -1.09 & 1.2 & $T \times M$ \\
\hline- & - & + & 1.09 & 4.49 & 0.77 & 3.09 & 0.78 & $F$ \\
\hline+ & - & + & 11.57 & 3.92 & -0.49 & 2.20 & -0.11 & $T x F$ \\
\hline- & + & + & 2.73 & 10.48 & -0.57 & -0.32 & -2.6 & $\mathrm{MxF}$ \\
\hline+ & + & + & 9.44 & 6.71 & -3.77 & -0.80 & -3.1 & $T \times M \times F$ \\
\hline
\end{tabular}

\subsection{Pseudocomponent Properties}

The physical and chemical properties of the coal pseudocomponents were determined with the Wilson and Prudich correlations. The predicted values for each run are presented in Tables 16 through 23.

\subsection{Location of Original Data}

Copies of the original data and calculation files are located at the MIT School of Chemical Engineering Practice, Bidg. 1505, ORNL. The laboratory book titled Pyrolysis contains coal-pyrolysis data and is located in Room 197, Bldg. 9201-3, Y-12 Plant. 
Table 16. Pseudoconponent Properties of Kentucky \#9 Coäl

\begin{tabular}{|c|c|c|c|c|c|c|}
\hline \multirow[b]{2}{*}{$\begin{array}{l}\text { Pseudocomponent } \\
\text { Boi ling-Point } \\
\text { Range } \\
\left({ }^{\circ} \mathrm{C}\right) \\
\end{array}$} & Retort Conditions: & \multicolumn{3}{|c|}{$\begin{array}{l}\text { Temperature }=623 \mathrm{~K} \\
\text { Particle sizz }=0 \text { to } 0 . \hat{\mathrm{c}} \mathrm{cm}\left(-{ }^{-} 0+0 \text { mes } \eta\right) \\
\text { Flow rate }=0.465 \mathrm{~L} / \mathrm{min}\end{array}$} & \multirow[b]{2}{*}{$\begin{array}{l}\text { Specific } \\
\text { Gravity } \\
\text { at } 289^{\mathrm{K}} \\
\left(60^{\circ} \mathrm{F}\right) \\
\end{array}$} & \multirow[b]{2}{*}{$\begin{array}{c}\text { Molecular } \\
\text { Weight }\end{array}$} \\
\hline & $\begin{array}{l}\text { Average } \\
\text { Boiling } \\
\text { Point } \\
\left({ }^{\circ} \mathrm{C}\right) \\
\end{array}$ & $\begin{array}{l}\text { Accumulated } \\
\text { Volume } \\
\text { Fraction } \\
\end{array}$ & $\begin{array}{l}\text { Critizal } \\
\text { Temperature } \\
(K)\end{array}$ & $\begin{array}{l}\text { Critical } \\
\text { Pressure } \\
\quad(\mathrm{MPa}) \\
\end{array}$ & & \\
\hline $50-100$ & 75 & 0.110 & & & & \\
\hline $100-150$ & 125 & 4.020 & 593 & 3.11 & 0.822 & 99 \\
\hline $150-200$ & 175 & 37.28 & 669 & 3.43 & 0.914 & 117 \\
\hline $200-250$ & 225 & 65.17 & 734 & 3.32 & 0.968 & 142 \\
\hline $250-300$ & 275 & 86.42 & 789 & 2.93 & 0.990 & 173 \\
\hline $300-350$ & 325 & 96.15 & 849 & 2.76 & 1.029 & $204:$ \\
\hline $350-400$ & 375 & 100.0 & 909 & 2.60 & 1.060 & 239 \\
\hline
\end{tabular}


Table 17. Pseudocomponent Properties of Kentucky \#9 Coal

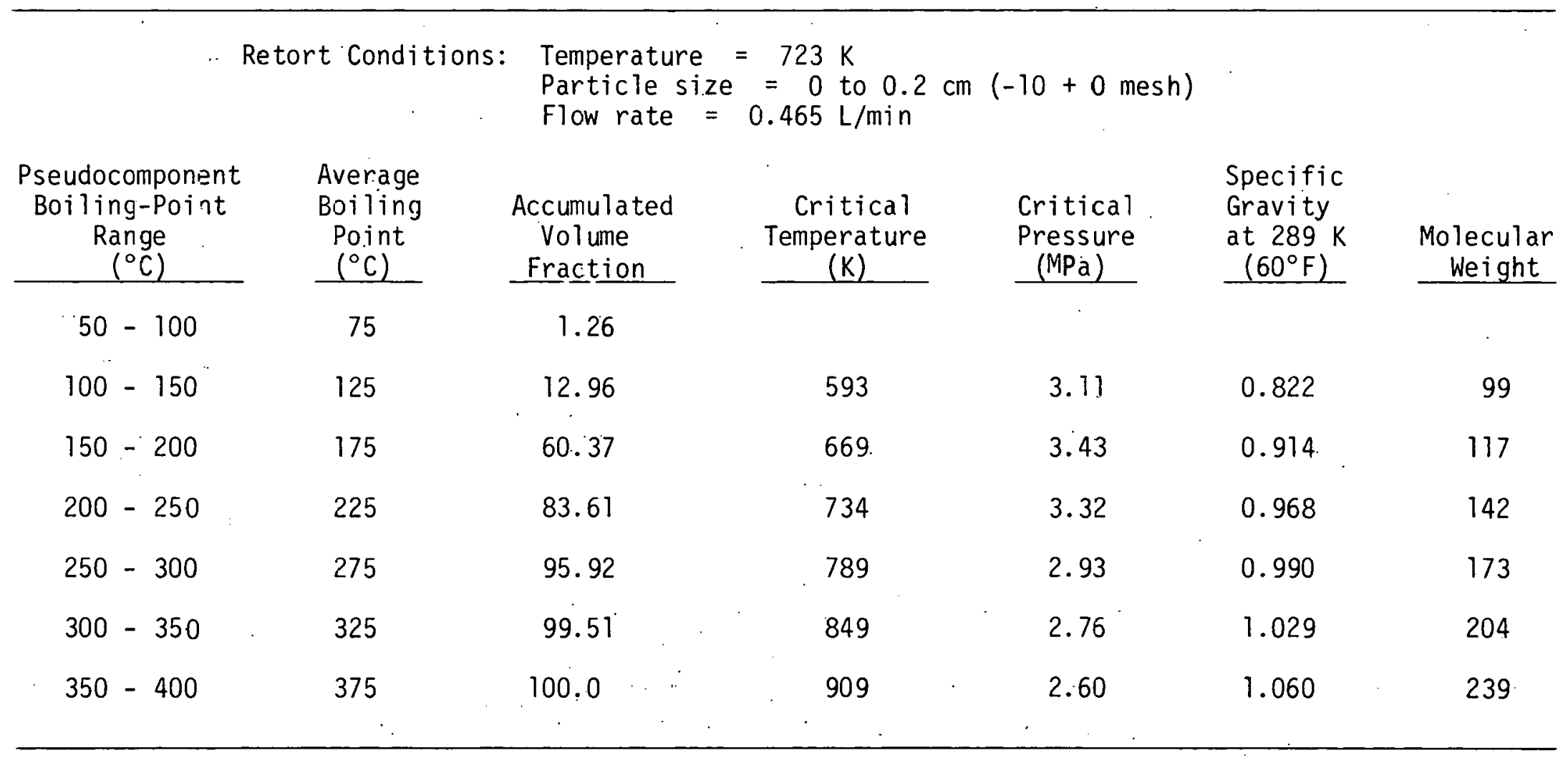


Table 18. Pseudoccmfonent Properties o= Kentuzky \#9 Coal

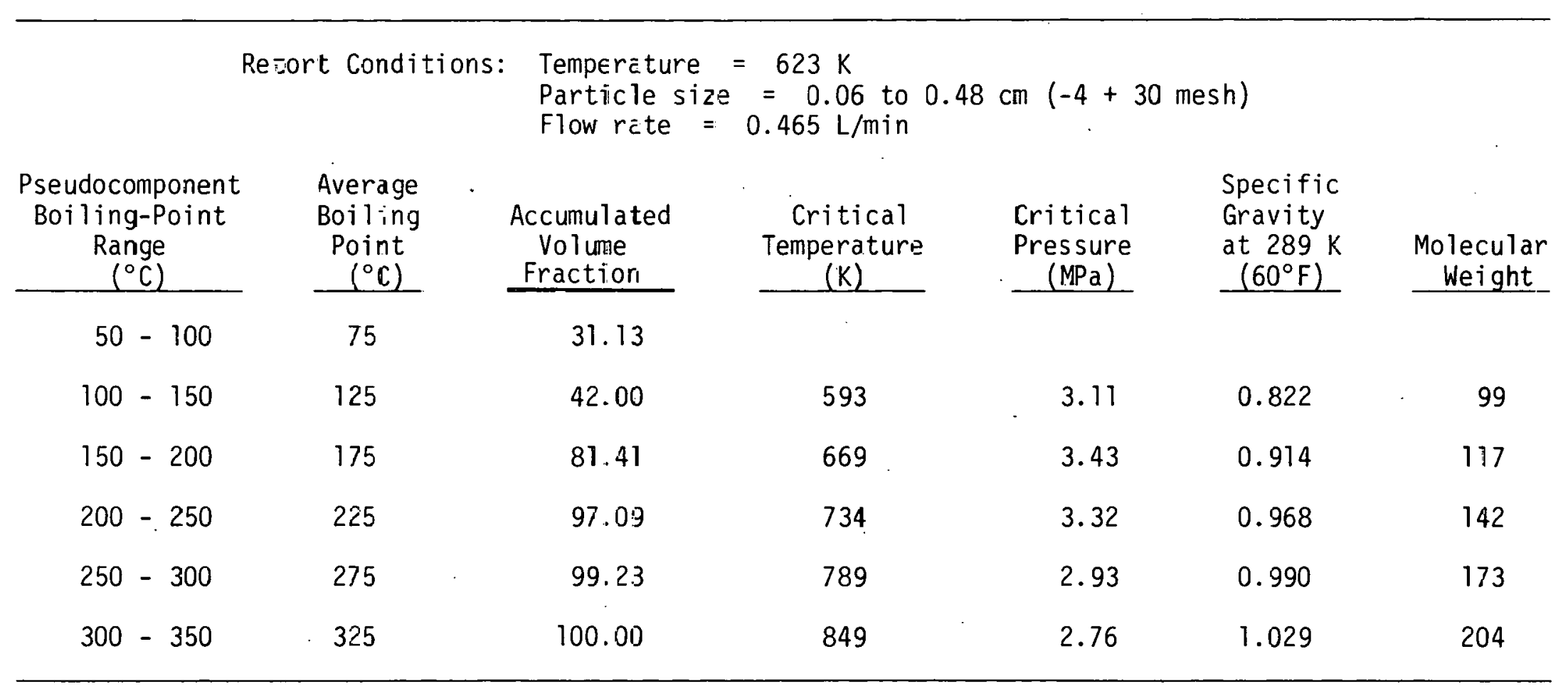


Table 19. Pseudocomponent Properties of Kentucky \#9 Coal

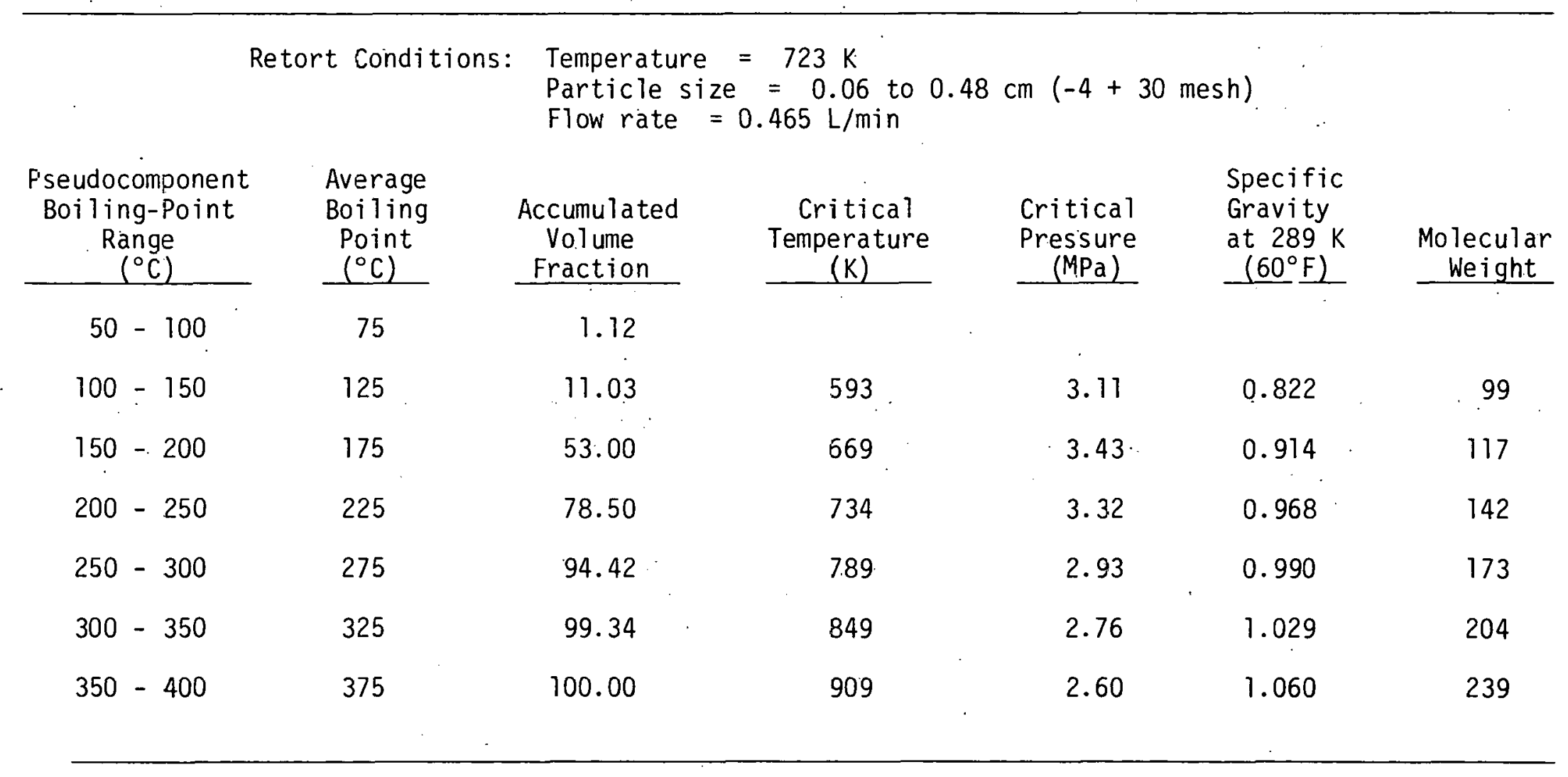


$\mathrm{Tab}^{-}$e il. Pseudocomponent Properties of Kentucky \#9 Coal

\section{Retort Conditians: Temperature $=623 \mathrm{~K}$ \\ Particle size $=0$ to $0.2 \mathrm{~cm}(-10+0$ mesin $)$ \\ Flow rate $=1.68 \mathrm{~L} / \mathrm{min}$}

\begin{tabular}{|c|c|c|c|c|c|c|}
\hline $\begin{array}{c}\text { Pseudocomponent } \\
\text { Boil ling-Point } \\
\text { Range } \\
\left({ }^{\circ} \mathrm{C}\right. \\
\end{array}$ & $\begin{array}{l}\text { fiveräge } \\
\text { Eoiling } \\
\text { Point } \\
{ }^{\circ} \mathrm{C} \text {. } \\
\end{array}$ & $\begin{array}{l}\text { Accumulated } \\
\text { Volume } \\
\text { Fraction } \\
\end{array}$ & $\begin{array}{c}\text { Critical } \\
\text { Temperature } \\
(\mathrm{K}) \\
\end{array}$ & $\begin{array}{c}\text { Critical } \\
\text { Pressure } \\
(\mathrm{MPa}) \\
\end{array}$ & $\begin{array}{l}\text { Specific } \\
\text { Gravity } \\
\text { at } 289 \mathrm{~K} \\
\left(60^{\circ} \mathrm{F}\right) \\
\end{array}$ & $\begin{array}{c}\text { Molecular } \\
\text { Weight } \\
\end{array}$ \\
\hline $50-100$ & 75 & 0.19 & & & & \\
\hline $100-150$ & 125 & 0.55 & 593 & 3.11 & 0.822 & 99 \\
\hline $150-200$ & 175 & 17.33 & 669 & 3.43 & 0.914 & 117 \\
\hline $200-250$ & 225 & $37.4 ?$ & 734 & 3.32 & 0.968 & 142 \\
\hline $250-300$ & 275 & 63.63 & 789 & 2.93 & 0.990 & 173 \\
\hline $300-350$ & 325 & 84.02 & 849 & 2.76 & 1.029 & 204 \\
\hline $350-400$ & 375 & 94.41 & 909 & 2.60 & . $\quad 1.060$ & 239 \\
\hline $400-450$ & 425 & 100.010 & & & & \\
\hline
\end{tabular}


Table 21. Pseudocomponent Properties of Kentucky \#9 Coal

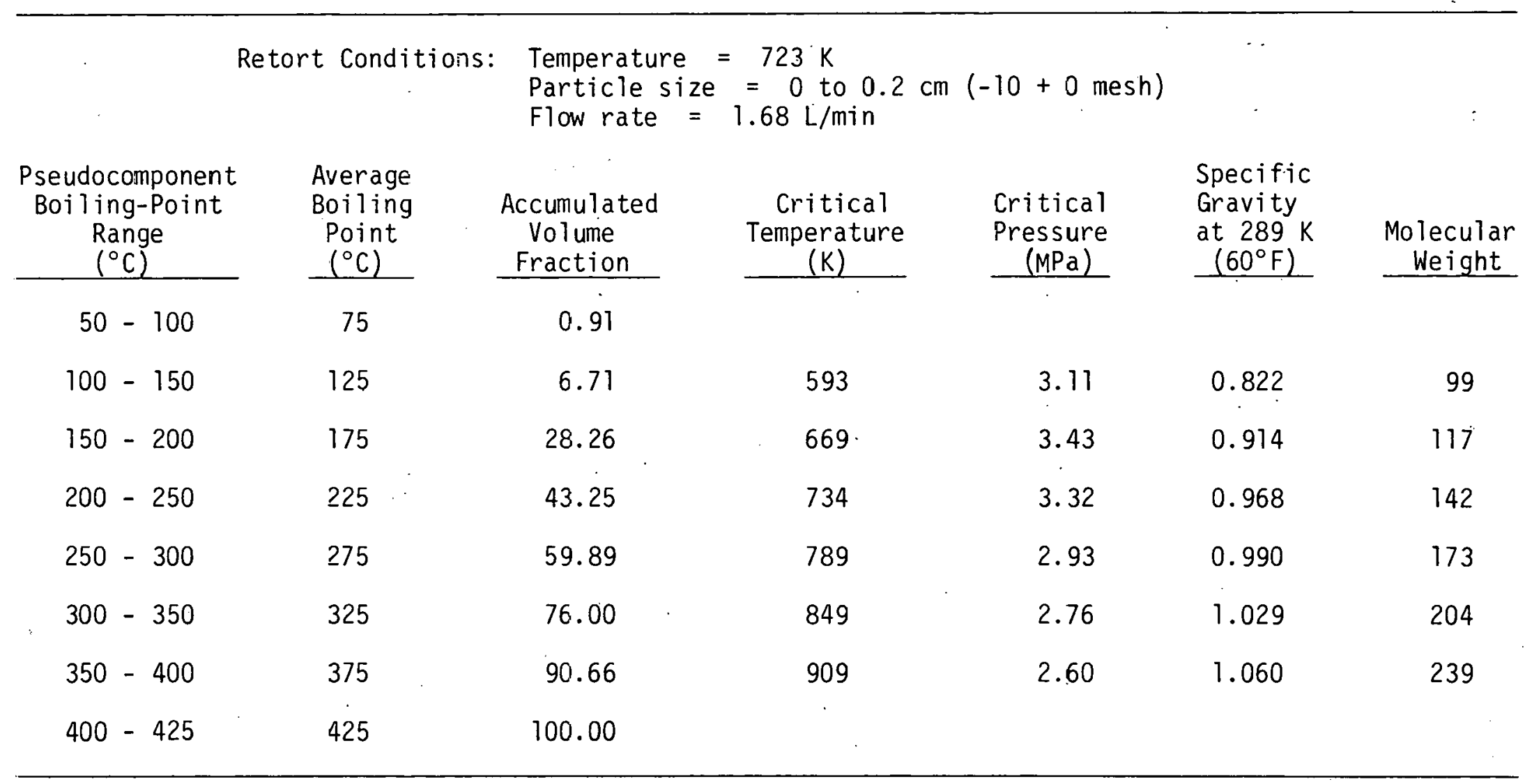


Table 22. Pseudocomponent Properties of Kentuiky \#9 Coal

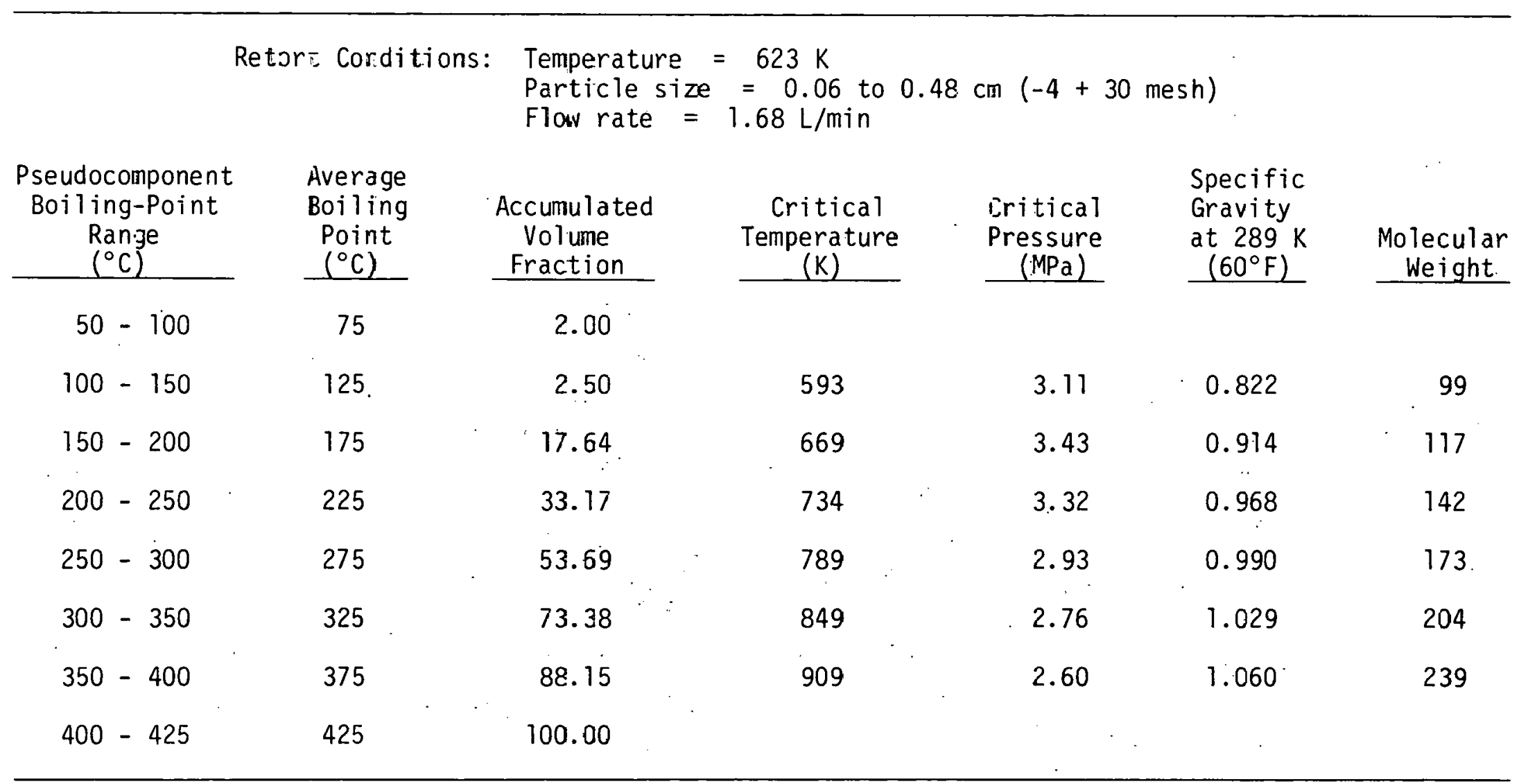


Table 23. Pseudocomponent Properties of Dean Seam \#3 Coal

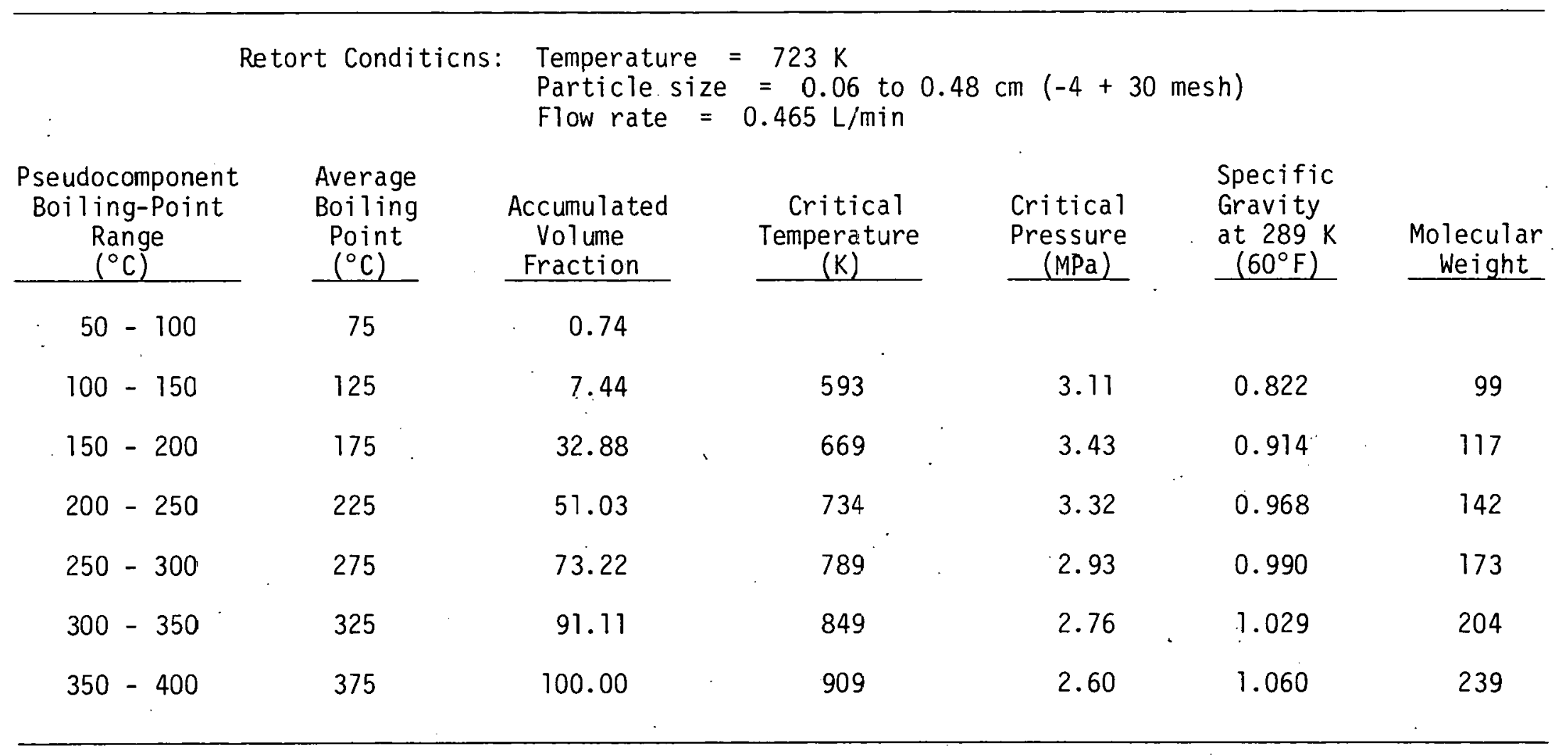




\subsection{Nomenclature}

a, b constants in heat capacity correlation, Eq. (21)

API American Petroleum Institute specific gravity

$\mathrm{C}_{\mathrm{p}} \quad$ heat capacity, $\mathrm{J} / \mathrm{kg}-\mathrm{K}$

$f_{0}, f_{1}$ Wilson parameters in Eqs. (17) and (18)

$F \quad$ purge-gas flow rate, L/min

$K_{w} \quad$ Watson characterization parameter

M particle diameter, cm

MW molecular weight

$\mathrm{P}_{\mathrm{C}} \quad$ critical pressure, $\mathrm{MPa}$

Sp.Gr. specific gravity at $289 \mathrm{~K}\left(60^{\circ} \mathrm{F}\right)$

$T$ temperature, $K$

$T_{b} \quad$ boiling point, $K$

$T_{C} \quad$ critical temperature, $K$

$T_{r} \quad$ reduced temperature

$v_{c} \quad$ eritical volume, cill $3 / 11101$

$x$ interaction between two factors

$y \quad$ response at $i^{\text {th }}$ retort condition

$Z_{c} \quad$ critical compressibility

$\omega$ acentric factor

Superscript

main effect in factorial statistical analysis

\subsection{Literature Réferences}

1. Attri11, J.A., personal communication, ORNL, May 12, 1982.

2. Baumeister, T., Marks' Standard Handbook for Mechanical Engineers, 8th ed., McGraw-Hil1, New York, 1961. 
3. Box, G.E., W.G. Hunter, and.J.S. Hunter, Statistics for Experimenters, Wi ley, New York, 1978.

4. Brantley, V.R., "Armes Char Production Facility," ORNL-IntraLaboratory correspondence, March 6, .1981.

5. Campbe11, J.H., and D.R. Stephens, "Kinetic Studies of Gas Evolution During Pyrolysis of Subbituminous Coal," Prepr. Am. Chem. Soc., Div. Fuel Chem., $21(7), 94$ (1976).

6. Fischer, F., The Conversions of Coal into 0i1s, Van Nostrand, New York, 1925.

7. Graves, R.L., personal communication, ORNL (May 3, 1982).

8. Gray, J.A., "Solvent Refined Coal (SRC) Process: Selected Physical, Chemical and Thermodynamic Properties of Narrow Boiling Range Coal Liquids for the SRC-II Process," Gulf Research and Development Co., Pittsburgh, April 1981.

9. Chemical Rubber Co., Handbook of Chemistry and Physics, 52nd ed., Cleveland, 1971.

10. Ho, C., personal communication, ORNL (April 30, 1982).

11. Howard, J.B., Chemistry of Coal Utilization, Second Supplementary Volume, Chapt. 12, Wiley, New York, 1981.

12. Howard, J.B., "Coal Pyrolysis - Product Yields and Properties: Survey," Conf. on Coal Pyrolysis, EPRI, Palo Alto, CA (Feb. 25-26, 1981).

13. Mark, L.S., Mechanical Engineers' Handbook, 4th ed., McGraw-Hill, New York, 1941.

14. Nelson, W.L., Petroleum Refinery Engineering, 3rd ed., McGrawHill, New York, 1949.

15. Peters, W., and H. Bertling, "Kinetics of the Rapid Degasification of Coals," Fuel, 44, 317 (1965).

16. Rubin, I.B., personal communication, ORNL, May. 12, 1982

17. Sass, A., "The Garrett Research and Development Process for the Conversion of Coal into Liquid Fuels," 65th Annual Am. Inst. Chem. Engrs. Meeting, New York, November 30, 1972.

18. Smith, I.W., "New Approaches to Coal Pyrolysis - CSIRO," Coal Pyrolys is Workshop, EPRI, Palo Alto, CA (February 1981).

19. Stewart, J.H., Jr., personal communication, ORNL, May 5, 1982. 
20. Tomkins, B.A., personal communication, ORNL, May 15, 1982.

21. Wojtowicz, R.J., and P.C. Bigot, "Analysis of Coal-Liquefaction Separations with Pseudocomponents," ORNL/MIT-344 (June 1982). 


\section{INTERNAL DISTRIBUTION}

1. V.R. Brantley

2. D.W. Burton

3. C.H. Byers

4. J.H. Clinton

5. C.S. Daw

6. D.M. Eissenberg

7. E.C. Fox

8-17. R.L. Graves

18. M.R. Guerin

19. J.R. Jones, Jr.

20. A.A. Khan

21. L.E. McNeese

22. G.E. Moore

23. M.L. Poutsma

24-28. J.H. Stewart, Jr.

29. J.F. Thomas

30. H.E. Trammell

31. R.G. Wymer

32-33. Central Research Library

34. Document Referenc; Section

35-37. Laboratory Records

38. Laboratovy Records, ORNL R.C.

39. ORNL Patent Office

40-54. MIT Practice School

\section{EXTERNAL DISTRIBUTION}

55. M.M. Alger, MIT, GE, Selkirk, NY 12158

56. J.B. Howard, MIT, Cambridge, MA 02139

57. G.A. Huff, Jr., MIT, Bethlehem Steel, Bethlehem, PA 18016

58. W.C. Rousseau, MIT, Cambridge, MA 02139

59. J.W. Tester, MIT, Cambridge, MA 02139

60. R.K. Helling, MIT, Bethlehem Steel, Bethlehem, PA 18016

61. J.E. Vivian, MIT, Cambridge, MA 02139

62. Morgantown Energy Technology Center P.0. Box 880, Morgantown, WV 26505

63. Office Asst. Mgr., Energy R\&D, DOE, Oak Ridge 64-90. Technical Information Center 